\title{
Supply-Side Liberalism: Fiscal Crisis, Post-Industrial Policy, and the Rise of the New Democrats
}

\author{
Brent Cebul
}

A new generation of liberals emerged in the 1970s, a decade of stagflation, deindustrialization, global capital flight, and public sector fiscal crises. Prevailing interpretations of New Democrats like Bill Clinton and Michael Dukakis explain their emphasis on entrepreneurialism and post-industrial sectors as the byproduct of cynical electoral strategies of "triangulation," that is, primarily as a reaction to the rise of Reagan Republicanism. This article instead positions their political economy as part of a much longer history of liberals' efforts to restructure the economy in order to stimulate new jobs and tax revenues that might also generate public revenue and support a progressive policy agenda. With roots in local, state, and regional industrial policies inspired by the New Deal, "supply-side liberalism" reemerged with force in the 1970s and 1980s, revealing heretofore unappreciated continuities that contextualize and clarify the origins of New Democrats' promotion of a set of seemingly "neoliberal" economic policies.

In 1980, as fiscal crises and inflating prices swept across the land, Lester Thurow, an economist whose political influence rose along with inflation, described the United States as The Zero-Sum Society, wracked by squabbles over taxation, welfare, and government budgets. Thurow was part of a growing set of ostensibly liberal economists and political theorists who raised fundamental questions about the ability of Western democracies to handle the entwined crises of inflation, technological change, and accelerating global financial interdependence. Some described how democratic welfare states had become "overloaded": bloated and then pillaged by "interest groups" that extracted unsustainable levels of public resources. A 1975 report argued that the emergency was less about economics and instead constituted a "crisis of democracy." For grassroots property tax protestors, pro-capitalist politicians, socialist theorists, "consensus" intellectuals, and liberal policy makers alike, the era's economic crises raised profound questions about the fiscal capacities and political legitimacy of democratic government. By the end of the 1970s, Americans of all stripes had become more keenly aware of distributional questions of governance- that is, of how to divvy up public goods-than at any time since the Great Depression. ${ }^{1}$

I would like to thank Lily Geismer, who generously read and commented on multiple versions of this article. I also thank Brian Balogh, Angus Burgin, Ben Holtzman, Margaret O’Mara, Charles Petersen, and the anonymous reviewers for Modern American History who read various drafts of this project and offered insightful criticism. My thanks also to Sarah Phillips and Brooke Blower for their editorial guidance and to Guian McKee, Robin Scheffler, and Mason Williams for numerous conversations over the course of many years that significantly improved this and other projects.

${ }^{1}$ Lester C. Thurow, The Zero-Sum Society: Distribution and the Possibilities for Change (New York, 1980). The Marxist sociologist Claus Offe argued that internal contradictions within democratic capitalism were exposed in the 1970s: "The contradiction lies precisely in the fact that stabilization policy organized via budgets has a structural effect that produces ever more far-reaching subsequent demands and claims." Claus Offe, "Crisis of Crisis Management': Elements of a Political Crisis Theory,” International Journal of Politics 6, no. 3 (Fall 1976): 29-67, here 59. See also Claus Offe, Contradictions of the Welfare State (Cambridge, MA, 1984). It was not only liberal and Marxist economists who sought to understand and perhaps remake political and economic policy. On debates about the rise of public choice theory and conservatives' neoliberal political-economy, see Nancy MacLean, (C) The Author(s) 2019. Published by Cambridge University Press 
Many so-called New Democrats, a group that came to include Bill Clinton, Michael Dukakis, Gary Hart, and Robert Reich, began their professional political lives in the 1970s. During the decade, this rising generation of American liberals took office as mayors, governors, state representatives, members of the U.S. House and Senate, and as policy advisors. And they did so at the moment when the era's economic stagnation threatened the public sector's ability to carry out functions that just a decade earlier had seemed axiomatic, many of which had constituted the material underpinnings of what scholars have called the "New Deal order" of liberal electoral dominance and social provision. In 1973, after Richard Nixon's landslide reelection to the presidency, Hart expressed his frustration with an American government that seemed to have become an inhumane and unresponsive juggernaut in the face of mounting domestic and international crises: "Nothing worked anymore. All the institutions were failing." ${ }^{2}$ By the mid-1980s, journalists, allies, and rivals tried to define the differing strands of young Democrats, many of whom shared Hart's frustrations. Some western and northeastern officials like Dukakis were dubbed Atari Democrats thanks to their veneration of new, entrepreneurial, high-technology sectors of the economy. This group, which included Hart and California Governor Jerry Brown, also sometimes called themselves "New Liberals" in an effort to signal their support for traditional liberal social values even as they pursued market-oriented and perhaps less bureaucratic ways of governing.

The other primary strand of New Democrats emerged from the South, often as selfconsciously "centrist" Democrats. Led by politicians like Georgia Senator Sam Nunn, the southern centrists echoed southern Democrats of the past in their skepticism for targeted welfare or antipoverty programs, and they also looked forward to stimulating the region's post-industrial and "post-racial" future. These Democrats would form the Democratic Leadership Council (DLC) in 1985, a policy development and political strategy organization intended to amplify their influence in the national party. By then, one supportive journalist divined certain political-economic affinities between these differing strands of Democrats and attempted to christen the entire cohort the "neoliberals." 3 Wile the nickname did not stick, these troupes of liberals were in fact uniting behind a rejection of the New Deal and Great Society's purportedly bureaucratic, centralized modes of governance and the party's seemingly outmoded emphasis on declining industrial sectors and "special interest groups." ${ }^{4}$ By the late 1980s and early 1990s, as their policy affinities, particularly their emphasis on new sectors of the economy, came to outweigh perceived regional distinctiveness, many of these liberals (and the journalists who covered them) simply embraced the label of "New Democrats."

Owing to their unabashed focus on the economy's supply side, a range of critics and scholars (some aligned with older Democrats) charged the New Democrats with a prejudiced disregard

\footnotetext{
Democracy in Chains: The Deep History of the Radical Right's Stealth Plan for America (New York, 2017); and Jennifer Burns, "Review of Democracy in Chains: The Deep History of the Radical Right's Stealth Plan for America by Nancy MacLean," History of Political Economy 50, no. 3 (Sept. 2018): 640-8. On concerns about a "crisis of democracy," see Daniel Sargent, A Superpower Transformed: The Remaking of American Foreign Relations in the 1970s (New York, 2015), 172. On public sector fiscal crises, see James O'Connor, The Fiscal Crisis of the State (New York, 1973). On the tax revolts, see Isaac William Martin, The Permanent Tax Revolt: How the Property Tax Transformed American Politics (Stanford, CA, 2008). On racism, distributional clashes, and welfare, see Marisa Chappell, The War on Welfare: Family, Poverty, and Politics in Modern America (Philadelphia, 2010); and Molly C. Michelmore, Tax and Spend: The Welfare State, Tax Politics, and the Limits of American Liberalism (Philadelphia, 2012).

${ }^{2}$ Gary Warren Hart, Right from the Start: A Chronicle of the McGovern Campaign (New York, 1973), 325.

${ }^{3}$ Randall Rothenberg, The Neoliberals: Creating the New American Politics (New York, 1984).

${ }^{4}$ On the "New Deal order" framework and periodization, see Steve Fraser and Gary Gerstle, eds., The Rise and Fall of the New Deal Order, 1930-1980 (Princeton, NJ, 1989). For an affirmative reappraisal, see Jefferson Cowie, The Great Exception: The New Deal and the Limits of American Politics (Princeton, NJ, 2016). On New Democrats and the new economy, see David Osborne, Laboratories of Democracy: A New Breed of Governor Creates Models for National Growth (Cambridge, MA, 1988). On the rise of Silicon Valley and the knowledge economy, see Margaret O'Mara, The Code: Silicon Valley and the Remaking of America (New York, 2019).
} 
for traditional manufacturing sectors, organized labor, minority constituencies, and the maintenance of a robust social safety net. ${ }^{5}$ These critics, along with some initial scholarly assessments, tend to explain New Democrats' reverence for entrepreneurialism, their neglect of social welfare programs, and their emphasis on a post-industrial economy as cynical byproducts of electoral calculations designed to "triangulate" between New Deal liberalism and the rising right. In this framework, New Democrats' policy ideas are often construed as little more than residual aspects of self-serving electoral calculations to abandon the New Deal and Great Society's core principles and polities. By the mid-1980s, critics like Jesse Jackson, who worked to unify an inclusive, multiracial, working-class coalition, sparred with many New Democrats: they were the branch of the party, Jackson charged, "who didn't march in the '60s and won't stand up in the '80s." Jackson declared that Biden reflected that branch of the party "who didn't march in the '60s and won't stand up in the '80s." These critical interpretations of the New Democrats have largely stuck, and for many good reasons. ${ }^{7}$ These critics appropriately condemn New Democrats for abandoning and, later, seeking to discipline working and poor people and people of color. Some recent scholarly interpretations build upon these critiques by situating the rise of Reagan-style conservatism as the primary engine driving the evolution of modern liberalism, positioning "neoliberal" Democrats as opportunistic helpmates to the age of Reagan.

Far from a politics of reaction or mere accommodation to modern conservatism, however, the New Democrats' support of high-tech entrepreneurs, their attention to the supply side of the economy, and their concern for governments' fiscal capacities, as well as their glaring blind spots for marginalized Americans, was an ethos that formed in the 1970s as they governed through fiscal crises and structural economic shifts. As the federal government and bastions of New Deal democracy like New York City faced fiscal crises and fractious distributional battles, all liberals worried their preferred social or economic policies would be locked away in fiscal-political cages wrought by stagflation and tax revolts. And, to be sure, a new generation of conservatives learned to exploit these issues for partisan gain. But as one midwestern mayor testified in 1974 before Congress's State and Local Governments Conference on Inflation, the situation was critical well before Reagan's revolution; as he put it, "we had better begin to think of where the cuts or the revenue are going to come from." In Los Angeles and

\footnotetext{
${ }^{5}$ Hillary Clinton's failed presidential bid in 2016 yielded a range of well-founded critical reassessments of the Clinton administration and the New Democrats. See, for example, Michelle Alexander, "Why Hillary Clinton Doesn't Deserve the Black Vote," The Nation, Feb. 10, 2016, https://www.thenation.com/article/hillary-clintondoes-not-deserve-black-peoples-votes/ [accessed May 21, 2019]; Chad Pearson, "Clinton and Kaine's Anti-Union Roots," Jacobin, Sept. 28, 2016, https://www.jacobinmag.com/2016/09/clinton-kaine-progressive-eraroosevelt-open-shop [accessed May 21, 2019]; and Jordan Weissman, "The Failure of Welfare Reform," Slate, June 1, 2016, https://slate.com/news-and-politics/2016/06/how-welfare-reform-failed.html [accessed May 21, 2019].

${ }^{6}$ Jack Germond and Jules Witcover, "Warning Shots: Biden, Jackson feuding," Philadelphia Inquirer, July 25, 1986, 13A.

${ }^{7}$ For scholarly and serious journalistic critiques of the New Democrats, see Thomas Byrne Edsall, The New Politics of Inequality (New York, 1985); E. J. Dionne, Why Americans Hate Politics (New York, 2004), 270-1; and Judith Stein, Pivotal Decade: How the United States Traded Factories for Finance in the Seventies (New Haven, CT, 2011). For a more measured critique that nevertheless supports a triangulation thesis, see Bruce Miroff, The Liberals' Moment: The McGovern Insurgency and the Identity Crisis of the Democratic Party (Lawrence, KS, 2007), 273-97. For a more sympathetic assessment, see Kenneth S. Baer, Reinventing Democrats: The Politics of Liberalism from Reagan to Clinton (Lawrence, KS, 2000).

${ }^{8} \mathrm{~A}$ recent scholarly appraisal advancing the triangulation thesis is Gary Gerstle, "The Rise and Fall (?) of America's Neoliberal Order," Transactions of the Royal Historical Society 28 (Dec. 2018): 241-64. Triangulation frameworks are especially understandable given the flourishing scholarship on modern conservatism. For an overview of this literature, see, Kim Phillips-Fein, "Conservatism: A State of the Field," Journal of American History 98, no. 3 (Dec. 2011): 723-43.

${ }^{9}$ The State and Local Governments Conference on Inflation, Washington, D.C., September 23, 1974: held at the request of President Gerald R. Ford and the Congress of the United States (Washington, DC, 1974), 7, available online via HathiTrust, https://catalog.hathitrust.org/Record/000028859 [accessed May 11, 2019].
} 
New York; in Congress and statehouses; in smaller, deindustrializing cities like Baltimore or Cleveland; and in poor, rural states like Arkansas, public officials, as the economic sociologist Greta R. Krippner argues, "kept coming back to what seemed to be the essence of the matter: there was only so much money." Wright Patman, Texas's venerable New Deal Democrat, was grim: "Unless we find some money, big money, there is not much we can do about housing," employment, or other social problems. ${ }^{10}$ For New Democrats, then, stimulating economic growth would be the way to transcend this zero-sum bind. Lester Thurow, who became the house economist for New Democrats like Massachusetts Senator Paul Tsongas, made the point succinctly: "If you have a growing economy, you don't have to choose between his claims on the national pie and your claims on the national pie." 11

Rather than signal a decisive break away from deeper liberal commitments, this politicaleconomic outlook had underappreciated roots in New Deal-era ideologies of governance and public finance. Stimulating new economic sectors through supply-side subsidies, many New Dealers believed, would also ensure robust and growing tax yields that would put their broader social policy agenda on a surer fiscal basis. This "supply-side liberalism," as I call it, found its earliest and fullest expressions in the National Resources Planning Board, local public and private uses of New Deal works spending, wartime defense contracting, and military Keynesianism. By the mid-1940s, vigorous, nationally directed, structural interventions in the economy came under conservative attack and faded. But New Deal-inspired industrial policies and their rationale in stimulating public revenue did not come to an end; rather, they were often localized. Precisely because southern states had always struggled with public sector austerity, the South and emerging Sunbelt received a disproportionate share of wartime and postwar spending designed to support supply-side or structural interventions. When the DLC was formed in the 1980s, many commentators viewed its emergence as a response to the Reagan Revolution. While they surely hoped to beat back the rising Republican tide, DLCers expressed their centrism through policies, institutions, and economic outlooks that reflected deep continuities with liberalism's supply side, particularly its southern, "color-blind," booster variant. ${ }^{12}$

\footnotetext{
${ }^{10}$ On Patman, see Greta R. Krippner, Capitalizing on Crisis: The Political Origins of the Rise of Finance (Cambridge, MA, 2011), 69.

${ }^{11}$ Though his focus in not on New Democrats, Jefferson Cowie describes how the left-liberal coalition understood the threat posed by economic decline to progressive policy and the New Deal and Great Society electoral coalitions: Stayin' Alive: The 1970s and the Last Days of the Working Class (New York, 2010), 241-4 and 268-9. On conservatives' cultivation of the tax revolts, see Robert O. Self, American Babylon: Race and the Struggle for Postwar Oakland (Princeton, NJ, 2003). The Senate held a series of hearings on "The Growing Threat of a Domestic Financial Crisis," which focused on the crisis of municipal finance due to volatility in the bond market associated with rising interest rates. As with savings accounts, inflation made low-yield municipal bonds a poor investment choice, and to compete with alternative investment instruments offering higher rates, municipalities were forced to offer higher and higher interest rates to secure capital essential for routine expenses like infrastructure maintenance. See generally, U.S. Congress, Senate, Subcommittee on Financial Markets of the Committee on Finance, The Growing Threat of a Domestic Financial Crisis, 93 Cong. 2nd sess., Aug. 7, 1974. See also, Advisory Commission on Intergovernmental Relations, Federalism in 1973: The System Under Stress (Washington, DC, Jan. 1974). On the impact of increased costs of financing municipal debt in New York City, see Kim Phillips-Fein, Fear City: New York's Fiscal Crisis and the Rise of Austerity Politics (New York, 2017), chs. 1 and 2. See also Alberta M. Sbragia, Debt Wish: Entrepreneurial Cities, U.S. Federalism, and Economic Development (Pittsburgh, 1996); and Todd Swanstrom, The Crisis of Growth Politics: Cleveland, Kucinich, and the Challenge of Urban Populism (Philadelphia, 1988). One of Tsongas's staff economists reported that the Senator had become "a Thurovian-if that's the word." Randall Rothenberg, “The Neoliberal Club," Esquire, Feb. 1, 1982, 37-46, here 45.

${ }^{12}$ On the New Deal, warfare state, and post-WWII liberalism's "supply side," see Brent Cebul, "They Were the Moving Spirits: Business and Supply-Side Liberalism in the Postwar South," in Richard R. John and Kim Phillips-Fein, eds., Capital Gains: Business and Politics in Twentieth-Century America (Philadelphia, 2017), 139-56. Alan Brinkley, The End of Reform: New Deal Liberalism in Recession and War (New York, 1995). For a similar argument on the localization of industrial policy, see Guian A. McKee, The Problem of Jobs: Liberalism, Race, and Deindustrialization in Philadelphia (Chicago, 2008). On the local uses of federal spending that took structural approaches to the economy, see Brent Cebul and Mason B. Williams, "Really and Truly a
} 
Across regions, and in dialogue as well as economic competition, New Democrats revived liberalism's supply side. As northern Democrats wrestled with their own public sector fiscal crises engendered by deindustrialization and entrepreneurial stagnation, many looked to the Sunbelt, the region that seemed to be thriving despite the era's crises. And as they did so, they updated a set of liberal policy preferences that had often relegated questions of equitable distribution, racial equality, and economic enfranchisement in favor of growth. ${ }^{13}$ Illuminating these lines of continuity helps to clarify the ways in which a diverse range of liberal actors converged on seemingly "neoliberal" policy prescriptions and political cultures. ${ }^{14}$

This article begins by recovering local, regional, and state-level policy action in the 1970s. As New Democrats wrestled with the realities of deindustrialization, capital scarcity, and public sector fiscal crises, many initially developed policies designed to save declining manufacturing sectors. ${ }^{15}$ As these efforts proved less successful or fiscally unsustainable (and as the industrial

Partnership": The New Deal's Associational State and the Making of Postwar American Politics," in Brent Cebul, Lily Geismer, and Mason B. Williams, eds., Shaped by the State: Toward a New Political History of the Twentieth Century (Chicago, 2019), 96-122; Philip J. Funigiello, The Challenge to Urban Liberalism: Federal-City Relations during World War II (Knoxville, TN, 1978); Rodger W. Lotchin, Fortress California, 1910-1961: From Warfare to Welfare (New York, 1992); and Margaret O’Mara, Cities of Knowledge: Cold War Science and the Search for the Next Silicon Valley (Princeton, NJ, 2005). See also Fred Block, "Swimming Against the Current: The Rise of a Hidden Developmental State in the United States," Politics and Society 36, no. 2 (June 2008): 169-206. On the significance of regionalism in shaping not only competitive approaches to development but also processes of interregional learning, see Andrew Needham and Allen Dieterich-Ward, "Beyond the Metropolis: Metropolitan Growth and Regional Transformation in Postwar America," Journal of Urban History 35, no. 7 (Oct. 2009): 943-69; and Andrew Needham, Power Lines: Phoenix and the Making of the Modern Southwest (Princeton, NJ, 2014), 268, note 55. On regional development policy and the direct connection between Kennedy and Jim Crow era boosters, see Cebul, "'They Were the Moving Spirits."”

${ }^{13}$ Triangulation frameworks tend to understate the ways in which liberal policies and preferences constitutive of the New Deal very often marginalized working people, the poor, and especially people of color and women-for example, with housing policy, urban development, mass incarceration, technology development, or token integrationist schemes. For examples of how twentieth-century liberalism entrenched or extended forms of marginalization, see Elizabeth Hinton, From the War on Poverty to the War on Crime: The Making of Mass Incarceration in America (Cambridge, MA, 2016); Arnold R. Hirsch, Making the Second Ghetto: Race and Housing in Chicago, 1940-1960 (Chicago, 1983); Nathan D. B. Connolly, A World More Concrete: Real Estate and the Remaking of Jim Crow South Florida (Chicago, 2014); Lily Geismer, Don't Blame Us: Suburban Liberals and the Transformation of the Democratic Party (Princeton, NJ, 2015); Ira Katznelson, When Affirmative Action Was White: An Untold History of Racial Inequality in Twentieth-Century America (New York, 2005); and Alice Kessler-Harris, In Pursuit of Equity: Women, Men, and the Quest for Economic Citizenship in 20th Century America (New York, 2003).

${ }^{14}$ This article contributes to a growing body of scholarship that locates a variety of contingent paths to and versions of neoliberalism. On the "versions of neoliberalism" thesis, see Lily Geismer, "Agents of Change: Microenterprise, Welfare Reform, the Clintons, and Liberal Forms of Neoliberalism," Journal of American History, forthcoming; and Stephanie L. Mudge, Leftism Reinvented: Western Parties from Socialism to Neoliberalism (Cambridge, MA, 2018). Timothy P. R. Weaver makes the valuable distinction between neoliberalism "by design" and neoliberalism "by default." See Timothy P. R. Weaver, Blazing the Neoliberal Trail: Urban Political Development in the United States and the United Kingdom (Philadelphia, 2016). For similar arguments that emphasize the contingent origins of varieties of neoliberalism, see Suleiman Osman, “'We're Doing It Ourselves,' The Unexpected Origins of New York City's Public-Private Parks during the 1970s Fiscal Crisis," Journal of Planning History 16, no. 2 (2017): 162-74; and Kim Phillips-Fein, "The History of Neoliberalism," in Cebul, Geismer, and Williams, eds., Shaped by the State, 347-62. See also, Krippner, Capitalizing on Crisis, and Phillips-Fein, Fear City. Other scholars have recently argued for the importance of identifying deeper historical continuities that challenge the notion that the neoliberal era constituted a decisive "turn" or "break" from earlier political and institutional arrangements and instead emerged from or through them. See, for instance, Nathan D. B. Connolly, "The Strange Career of American Liberalism," in Cebul, Geismer, and Williams, eds., Shaped by the State, 62-95; and Amy C. Offner, Sorting Out the Mixed Economy: The United States, Colombia, and the Rise and Fall of Welfare and Developmental States (Princeton, NJ, 2019).

${ }^{15}$ Despite a rich and growing literature on local efforts to overcome the strains of deindustrialization, the most influential accounts of the political responses to deindustrialization focus on national policy debates. See especially 
policy debate moved to the national level in the 1980s), economists, entrepreneurs, and development consultants alerted state and local officials to a related crisis of entrepreneurship, innovation, and productivity. Alongside support for declining sectors, then, a range of $\mathrm{New}$ Democrats, including Governors Dukakis (Massachusetts), Clinton (Arkansas), and Brown (California), explicitly borrowed from one another as they experimented with programs to jumpstart or sustain new post-industrial sectors of the economy. They created public venture capital funds in which states took equity stakes in businesses, public and quasi-public business incubators, and state-supported public-to-private research and development initiatives. As these efforts began to generate positive returns, some of which far exceeded expectations, New Democrats more confidently believed their economic programs, their post-industrial policies, were the key to slipping out of austerity's zero-sum bind.

Excavating the flurry of state and local post-industrial policy in the 1980s also suggests certain weaknesses of "triangulation" frameworks. Precisely because these frameworks dismiss the degree to which politicians such as Bill Clinton genuinely believed they had discovered solutions for stimulating the economy and tax yields as well as solving unemployment and poverty, these accounts underestimate the seductive staying power of New Democrats' political and economic ethos. Capturing the origins of this confidence, then, is essential for understanding the blind spots and biases New Democrats developed when it came to protecting the social safety net and defending marginalized Americans. This outsized faith in growth emerged across regions and over time as New Democrats, white males almost all, exchanged more than just best practices for stimulating new economic sectors. By the late 1980s, they entrenched and reinforced paternalistic understandings of the intrinsic value of their sober, fiscal stewardship of the state and economy, ultimately to the exclusion of other constituencies. And, in their rush to draw contrasts with a caricaturized vision of New Deal statism, New Democrats also failed to develop a positive language to defend the government's role in their development programs, to say nothing of defending a broader social agenda. In this way, again, this younger generation of Democrats was not so different from its mid-century forbears, whose Cold War-era tendency to submerge active state policies beneath a rhetoric of supposed free markets, earned benefits, and associational partnerships placed the legitimacy of an active state on a thin conceptual foundation. ${ }^{16}$ In the $1970 \mathrm{~s}$, and as that state came in for new attacks in the wake of Vietnam, New Left and New Right critiques, and its failure to master the economic crises, Americans from across the political spectrum looked for alternatives to centralized political

Otis L. Graham, Losing Time: The Industrial Policy Debate (Cambridge, MA, 1992); Cowie, Stayin' Alive, 261-312; and Stein, Pivotal Decade. The many accounts of local responses to deindustrialization include McKee, The Problem of Jobs; Thomas Dublin and Walter Licht, The Face of Decline: The Pennsylvania Anthracite Region in the Twentieth Century (Ithaca, NY, 2005); David Koistinen, Confronting Decline: The Political Economy of Deindustrialization in Twentieth-Century New England (Gainesville, FL, 2016); Tracy Neumann, Remaking the Rust Belt: The Postindustrial Transformation of North America (Philadelphia, 2016); and Chloe Taft, From Steel to Slots: Casino Capitalism in the Postindustrial City (Cambridge, MA, 2016). On the importance of the local state in understanding national political developments, see Thomas J. Sugrue, “All Politics Is Local: The Persistence of Localism in Twentieth Century America," in Meg Jacobs, William J. Novak, and Julian Zelizer, eds., The Democratic Experiment (Princeton, NJ, 2003), 301-26. For an example of the importance of reintegrating state governments into American political history, see Karen M. Tani, States of Dependency: Welfare, Rights, and American Governance, 1935-1972 (New York, 2016).

${ }^{16}$ On mid-century liberalism's tendency to emphasize market actors, associationalism, and hiding redistributional social benefits, see David M. P. Freund, "Marketing the Free Market: State Intervention and the Politics of Prosperity in Metropolitan America," in Kevin M. Kruse and Thomas J. Sugrue, eds., The New Suburban History (Chicago, 2006) 11-32; Brian Balogh, The Associational State: American Governance in the Twentieth Century (Philadelphia, 2015); Christopher Howard, The Hidden Welfare State: Tax Expenditures and Social Policy in the United States (Princeton, NJ, 1997); and Suzanne Mettler, The Submerged State: How Invisible Government Policies Undermine American Democracy (Chicago, 2011). 
authority even as they continued to seek to bend federal powers to benefit themselves and their communities. $^{17}$

\section{Private and Public Fiscal Crises in the 1970s}

The crises of the 1970s extended well beyond familiar histories of oil shocks, stagflation, and deindustrialization. Those forces and others, such as foreign capital flight, contributed to a crisis of capital liquidity, entrepreneurialism, and innovation. Domestic private sector spending on research and development, a key source of innovation and productivity gains, stagnated at the very moment when competitor nations like West Germany and Japan pumped public funds into industrial policies and R\&D. Similarly, the venture capital industry, a relatively new player on the development scene in the 1960s, all but disappeared. In 1969, total venture capital in the United States funded some $\$ 170$ million in new investments; in 1975, the total was $\$ 10$ million. The number of patents issued in the United States also plummeted, dipping 31 percent between 1971 and 1984. More striking still, 1,000 companies went public in 1969; over the four-year period between 1973 and 1977, just 100 did so. American innovation seemed to have run aground. "No subject is more central to our hopes for the future," said William Simon, President Ford's Secretary of the Treasury, than the question of capital formation for innovation. Conservative groups like the Business Roundtable argued that high marginal tax rates "caused a low rate of savings in the United States," which dragged down new investments and, eventually, the economy. But conservatives' emphasis on the "supply side" of the economy, critics correctly surmised, was primarily economic cover for political assaults on labor and the taxes that underwrote the liberal welfare state. ${ }^{18}$ Meanwhile, many other businesspeople knew there were more ways to stimulate capital formation than cutting taxes. As they had since the New Deal, they looked to government.

Local boosters, chambers of commerce, and the lawyers, bankers, and developers who depended on local markets knew that liberalism had always had a supply side that flowed through federal spending and contracts. Beginning in the New Deal era, these boosters recruited a vast array of subsidies with which they made structural interventions in local markets. A number of New Deal economists articulated a rationale for sustaining these subsidies, used to spur significant economic reforms in "underdeveloped" regions, in Saving American Capitalism: A Liberal Economic Program (1948). As Seymour Harris, the volume's editor, explained, "The TVA programs, research help, provision of capital-all of these" had become a "means of putting industry in the newer areas on a fair competitive basis with the East." "[P] rosperity depends on both supply and demand," and to ensure adequate supply, "we need more spending for research, both pure and applied ... and we want an incentive system which will assure ... correction of structural maladjustments." These economists "learned that

\footnotetext{
${ }^{17}$ Suleiman Osman argues that "the politics of scale" is essential to capturing the complex political dynamics of the 1970s. Osman, "Glocal America: The Politics of Scale in the 1970s," in Cebul, Geismer, and Williams, eds., Shaped by the State, 241-60.

${ }^{18}$ Peter K. Eisinger, The Rise of the Entrepreneurial State: State and Local Economic Development Policy in the United States (Madison, WI, 1989), 80; Barry Bluestone and Bennett Harrison, The Deindustrialization of America (New York, 1984), 128; and Krippner, Capitalizing on Crisis, 61-73. On West German and Japanese industrial policy, see Günter Heiduk and Kozo Yamamura, eds., Technological Competition and Interdependence: The Search for Policy in the United States, West Germany, and Japan (Seattle, 1990); Margaret O'Mara, "Startup Cowboys and High-Tech Pioneers: The Political Construction of Entrepreneurial Leadership," unpublished conference paper, Organization of American Historians Annual Meeting, Apr. 2016, Providence, $\mathrm{RI}$, in author's possession. On the origins of the venture capital industry, see Kim-Mai Cutler, "The Unicorn Hunters," Logic 4, May 15, 2018, https://logicmag.io/04-the-unicorn-hunters/ [accessed May 21, 2019]; Peter Milius, "The Capital Shortage Issue," Washington Post [hereafter WP], July 14, 1975, A1; Kim Phillips-Fein, Invisible Hands: The Making of the Conservative Movement from the New Deal to Reagan (New York, 2010), 194-5.
} 
by putting unemployed men and money to work, the nation's income and wealth would multiply." Liberals' more familiar demand-side vision-employing the unemployed to enhance purchasing power-was paired with a supply-side vision-mobilizing "unemployed" money-to support what we would today call industrial policies. The New Deal and warfare states inspired a vast array of public and private partnerships led by planning officials, chamber of commerce leaders, and university-trained development experts, and in the postwar years, these actors linked funds for housing, slum clearance, highways, "area redevelopment," university R\&D, and defense spending to restructuring local markets. ${ }^{19}$

That the federal government especially lavished these funds on southern states underscored the other rationale for liberalism's supply side: generating tax revenues, which New Dealers often termed "public wealth." Liberals worried that southern states in particular lacked the fiscal capacity to sustain the New Deal's social agenda. As Franklin Roosevelt put it in 1934, the region's poverty was so entrenched because of a vicious cycle. Roosevelt explained that southern states lacked equal social opportunities and economic capabilities not because of Jim Crow, but because their "taxing power was almost nil"; "there is nothing to tax." Federal subsidies, then, would create more than merely short-term employment. They would jumpstart economic developments that would generate tax revenues to support broader social and economic policies. This progressive rationale for creating "public wealth" by stimulating a taxable base of private capital would animate liberalism's supply side, whether under the New Deal or under New Democrats. Often, the most effective structural interventions used a blend of federal and state funds to subsidize entirely new sectors: the high-tech defense industry in southern California, the Research Triangle Park in North Carolina, or "cities of knowledge" in Silicon Valley, Atlanta, or along Route 128 in Massachusetts. ${ }^{20}$ Yet, because these subsidies were often authorized for a broad national agenda somewhat adjacent to economic growth — such as winning the Cold War-their role in restructuring markets often flew beneath national political debates and, thus, most citizens' awareness. Essential to the persistence of liberals' supply-side stimulus, then, was its decentralization and its ability to take on assumed identities afforded by broader prerogatives. ${ }^{21}$ This anonymity and the amnesia it abetted would become a liability.

Indeed, by the early 1970s, these wider justifications were wearing thin. The Vietnam War and détente eroded Congress's deference to defense spending; urban renewal, with its feint toward improved housing for the poor, was widely reviled; and the Nixon administration had slashed or block granted much of the Great Society's development subsidies, beginning the slide toward Reagan's devolution. Local elites possessed the instincts and institutions, but not an acceptable discourse or credible cause, to call forth new rounds of stimulus. The urban North, wracked by uprisings, deindustrialization, and budget shortfalls, saw its economic, political, and social order unravelling. And northern distinctiveness was significant in other ways, too: while business failure was an evenly distributed geographical fact during the 1970 s, the rate of northern business startups lagged desperately behind the rest of the nation. ${ }^{22}$ A new generation of liberals took office across the North, and they looked South for new growth strategies.

\footnotetext{
${ }^{19}$ Seymour Harris, ed., Saving American Capitalism: A Liberal Economic Program (New York, 1948), 7-8; Cebul and Williams, "'Really and Truly a Partnership."

${ }^{20}$ Franklin Roosevelt, Press Conference in Warm Springs, GA, Nov. 23, 1934; Michael I. Luger and Harvey A. Goldstein, Technology in the Garden: Research Parks and Regional Economic Development (Chapel Hill, NC, 1991); and O'Mara, Cities of Knowledge.

${ }^{21}$ One notable exception serves to reinforce the broader point. The Area Redevelopment Administration was designed to explicitly industrialize regions being left behind by deindustrialization or rural outmigration. But its short and fraught lifespan (1961-1965) and its ambivalent legacy fits the broader pattern. On the ARA, see Gregory S. Wilson, Communities Left Behind: The Area Redevelopment Administration, 1945-1965 (Knoxville, TN, 2009).

${ }^{22}$ Eisinger, The Rise of the Entrepreneurial State, 81.
} 
The midterm elections of 1974 are remembered for the arrival of the "Watergate babies" in the House of Representatives, but the New Democrats' first electoral wave was broader and deeper still. Younger liberals elected to new positions in 1974 included Oklahoma Governor David Boren; California Governor Jerry Brown; New York State Assembly member Chuck Schumer; Massachusetts Governor Michael Dukakis; Connecticut Governor Ella Grasso; Colorado Senator Gary Hart and Governor Richard Lamm; and Vermont Senator Pat Leahy (in Arkansas, Bill Clinton narrowly lost his first bid for Congress in a highly conservative district). Across the country, but especially in the Northeast and Midwest, these newly elected Democrats confronted state and local governments teetering on the brink of fiscal ruin. Just as inflation chewed up the value of consumers' dollars, it rapidly undermined state and municipal budgets and purchasing or contracting power. Some of these younger Democrats consciously signaled their frugality, embracing the moniker "new liberals" to emphasize their pursuit of maintaining older policy commitments in new, more economical ways. As the Los Angeles Times reported in 1975, “The New Liberalism's symbols of austerity have attracted the most attention: Brown in a simple bachelor pad. Dukakis riding a streetcar to the Massachusetts statehouse in Boston." Older ways of governing, the Times noted, appeared to them "outmoded in a time of recession and shortages." 23 Across partisan and generational lines, the collective mood was grim. At the 1974 State and Local Government Conference on Inflation, a summit convened by President Ford to assess the crisis, officials shared a litany of woe. On the eve of voters' mobilization against property taxes-the lifeblood of local governments-President Ford blamed federal aid to state and local governments (which accounted for 23 percent of state and local budgets in 1973) for the rapidly rising inflation. ${ }^{24}$

With this infusion of new liberals and a growing sense of desperation, Massachusetts Congressman Michael Harrington organized the Northeast-Midwest Congressional Coalition (NMCC) of Democrats to work from within Congress to revise federal funding formulas in ways that might favor northern cities and regions and to foster regional economic planning. If northern Democrats had forgotten about liberalism's supply side, looking to the South offered a live lesson. "Regionalism," Harrington said, "which everyone [in the North] decries, has been a Southern specialty for the better part of the post-Civil War period." As an ally explained, "We're trying to learn what you people ... have known for a long time-how to make the federal government responsive." The South, said Harrington, "taught us some valuable lessons ... about long-range planning and what a region needs" to generate growth. Southerners had enjoyed favorable federal funding status since 1938, when Franklin Roosevelt declared the region the nation's number one economic problem. "Now it's our turn," said Harrington. Over 200 members of Congress joined Harrington's coalition and mobilized with a sense of sectional grievance-this, too, a historical southern specialty. With the support of unions, members generated publicity detailing how little "equity" northerners received from their federal taxes. New England newspapers highlighted states' $\$ 30$ billion deficit in taxes paid versus services or contracts received. The Chicago Tribune reported the Midwest received less equity than New England. A New York Times headline alerted readers: "New York State is Shortchanged on Federal Aid." ${ }^{25}$

\footnotetext{
${ }^{23}$ Bill Boyarsky, "Democrats' 'New Liberals' Find Woes in Austerity Plan," Los Angeles Times [hereafter LAT], November 30, 1975, 1.

${ }^{24} \mathrm{New}$ England, the Mid-Atlantic, and the Great Lakes states lost the most public purchasing power owing to the high fixed costs associated with their more generous social welfare commitments, a higher dependency on fixed federal aid, and declining revenue due to deindustrialization and population loss. See Appendix C, "The Impact of the Economy on State and Local Budgets: Regression Analysis," in Advisory Commission on Intergovernmental Relations, "State-Local Finances in Recession and Inflation: An Economic Analysis" (Washington, DC, 1979), 73-82; and "The State and Local Governments Conference on Inflation."

${ }^{25}$ "Mr. Harrington Responds," Wall Street Journal [hereafter WSJ], Feb. 11, 1977, 8; "South, Southwest May Counterattack: 'Frostbelt' Gains in Fight for U.S.," LAT, Nov. 13, 1977, A1; "It's Frostbelt vs. Sunbelt for U.S.
} 
The origins of the Southern Growth Policies Board (SGPB), based at North Carolina's Research Triangle Institute, offered northerners a lesson in how federal funds seemed to be driving the Sunbelt boom. When he established the Research Triangle in the 1950s, North Carolina Governor Luther Hodges argued that R\&D could pack "tremendous economic wallop." Hodges, a textile manufacturer turned politician who openly opposed Brown v. Board, served as governor in the 1950s and as President Kennedy's Commerce Secretary, becoming an ideological bridge between conservative, southern New Deal Democrats and later centrist, "New South" Democrats like Jimmy Carter. By the late 1950s and 1960s, Hodges and a cohort of younger southern Democrats established the SGPB to use federal subsidies and contracts to expand local capital, nurture $\mathrm{R} \& \mathrm{D}$, and increase productivity and wage rates to create a hightech, high-wage manufacturing economy.

As northern leaders studied Sunbelt development strategies, they might also have learned that these initiatives were often modeled on negative northern examples. By the late 1960s and early 1970s, a number of southern Democrats like Carter, who self-consciously cultivated "centrist" or moderate positions between older style massive resistance Democrats and Civil Rights liberals, joined Hodges in reassessing the industrialization model the South had pursued for nearly a century, which some derided as "smokestack chasing." One ally hoped to avoid "turning our landscapes into [the] industrial wastelands" they saw littering the North and began emphasizing quality of life issues that might appeal to suburban voters. ${ }^{26}$

But deindustrialization and pollution were just part of the crises facing the North. Concerns about mobilized and militant African Americans-and particularly centrists' desires to promote the notion of a "post-racial" South-were also key components of their politics. As these southern Democrats eyed the broader urban crisis, characterized by entrenched poverty and violence, they understood it primarily as a racial crisis caused by the influx of African Americans who pursued industrial jobs. In 1971, Duke University president and former North Carolina Governor Terry Sanford organized a conference, "The Urban South: Northern Mistakes in a Southern Setting?," in hopes of generating support for his SGPB idea: a partnership between elected officials and southern business leaders to use Research Triangle assets to "manage" the transition from "smokestack chasing" to post-industrial economies. Tellingly, West Virginia Governor Arch Moore hoped a "Growth Policies Board" would "save us from the fate of all of the New Yorks and the Newarks and the Philadelphias and the Detroits in this country" - cities that had seen some of the most dramatic revolts by oppressed African Americans in the late 1960s. Thirteen southern states became dues-paying members of the SGPB, and as they did, they fused their vision of a high-tech economy with their sense that, in the wake of the Civil Rights and Voting Rights Acts, the South would now enter a "postracial" future. This future would be built on the kinds of high-wage, high-education, high-tech jobs generally denied to the vast majority of African Americans. In the context of ongoing racial discrimination and glaring racialized poverty and inequality, the governors' optimism about their "post-racial" vision strained credulity. Covering a subsequent meeting in Durham, the

funds," Cleveland Plain Dealer, [hereafter PD], Oct. 23, 1977, 8; "North-Midwest Coalition Imitates South," Raleigh News and Observer, May 22, 1977, folder Southern Growth Policies Board, RCB-16535, Georgia Archives, Morrow, GA [hereafter GAA]. On labor's efforts to court federal spending to stem deindustrialization in Massachusetts, see Koistinen, Confronting Decline, 214-6; "House Group Wants to Stem Sunbelt Flow," WP, Sept. 2, 1976, B1; "U.S. Aid Lopsided: Walker," Chicago Tribune [hereafter CT], Dec. 15, 1976, b6; "New York State is Shortchanged on Federal Aid, New Study Finds," New York Times [hereafter NYT], July 4, 1977, 14.

${ }^{26}$ Bruce J. Schulman, From Cotton Belt to Sunbelt: Federal Policy, Economic Development, and the Transformation of the South, 1938-1980 (Durham, NC, 1994), 169; "An Exciting Beginning," Anniston Star, May 13, 2012, https:/www.annistonstar.com/opinion/h-brandt-ayers-an-exciting-beginning/article_02620f1f58a2-5f6e-9235-04f558b86b51.html [accessed May 11, 2019]. On the connections between the rise of suburbs, quality of life politics, and environmental concerns, see Samuel P. Hays, Beauty, Health, and Permanence: Environmental Politics in the United States, 1955-1985 (New York, 1989). 
Washington Post reported that southern Democrats had, "by simple fiat, declared an end to racism." One supporter of the SGPB recalled the mood: "it was a Southern Epiphany." As South Carolina's Governor John West put it, their work heralded "a truly post-racial society." Sanford used a misplaced and nauseating historical metaphor to proclaim his excitement: after "a century of being the whipping boy and backward child ... [ $t$ ]he South can lead the nation, must lead the nation." 27

Georgia's Governor Jimmy Carter chaired the Board in 1973-1974, and he shepherded its first major report. Two hundred economic consultants, scholars, political leaders, and businesspeople recommended creating "technical programs" for each state and subregion to target specific industries, technologies, and new markets based on local resources. Consultants like Walt Whitman Rostow, the influential Cold War development mandarin, urged leaders to aggressively subsidize R\&D. Others detailed the critical importance of federal funds in underwriting infrastructure and business recruitment: the funds could meet the "capital requirements for financing the South's economic expansion." Politicians had to master "the flow of federal funds into the South" and ensure "the adequacy of state and local tax bases to support" innovation, social services, and infrastructure. ${ }^{28}$

Accounts of the Sunbelt-Frostbelt wars over federal funding formulas and tax equity, which generated many headlines in the mid-1970s, obscured the fact that officials organized in mirror image to compete for federal subsidies to fund structural economic reforms. To counter Harrington's organizing in the North, in 1978 Georgia governor and SGPB chairman George Busbee encouraged southern municipal leagues, chambers of commerce, and councils of cities to join the Board's Local Government Advisory Council to form local growth partnerships, "the building blocks of commerce and government." But he especially urged them to lobby Congress to continue favoring the region. Meanwhile, northerners saw that increased aid alone was not an effective growth strategy. A 1977 report, "Revitalizing the Northeastern Economy," produced by a Columbus, Ohio, think tank and Boston's Council for Northeast Economic Action, found that "a set of antagonisms" between business, labor, and government had been "destructive to the long-run interests of all." As National Journal summarized it, "business has come to feel that government in many parts of the Northeast is ineffective, fragmented, hostile, and uninterested in the very programs needed to underwrite economic renewal." "Smug insularity and complacency have held on rather grimly," Harrington lamented. Complacency fed stagnation, and Harrington worried that northern states lacked the South's dynamic political-economic vision. Economists at the First National Bank of Boston called for a domestic version of Truman's Point Four Program to link "financial blessings from Washington" with reindustrialization. Harrington called for a Tennessee Valley Authority for the North. ${ }^{29}$ Though these proposals floundered, they reflected the ubiquity of

\footnotetext{
27“Compact Set Up for 'Post-Racial' South,” NYT, Oct. 5, 1971, 26. Member states included Alabama, Arkansas, Georgia, Kentucky, Louisiana, Mississippi, Missouri, North Carolina, Oklahoma, South Carolina, Tennessee, Virginia, and West Virginia. Some Republican governors were involved, but the SGPB's most enthusiastic proponents were Democrats; "SGPB: An Exciting Beginning," Southern Growth Policies Board 40th Anniversary Commentaries, 7-8; "Another of the 'New Souths," WP, Oct. 10, 1971, F1.

${ }^{28}$ William L. Bowden to Governors of the Southern States, July 8, 1974, folder Executive Committee, May 17, 1974, box 22, subseries 1.3, Southern Growth Policies Board Papers, UNC Chapel Hill, NC [hereafter SGPBP]; William L. Bowden, "Purposes of the Southern Growth Policies Board," Apr. 4, 1975, folder Executive Committee, Apr. 4, 1975, box 23, subseries 1.3, SGPBP; W. W. Rostow, "The South and the Future of the American Economy," Feb. 24, 1978, folder Southern Growth Policies Board, RCB-16535, GAA; "National Growth Policy Research on the South," attached to Minutes, Executive Committee Meeting, Sept. 24, 1976, folder Executive Committee, Sept. 23-24, 1976, Oklahoma City, box 23, subseries 1.3, SGPBP.

29“"The Second War Between the States," Business Week, May 17, 1976, 92-5; Joel Haverman, "Federal Spending: The North's Loss Is the Sunbelt's Gain,” National Journal, June 26, 1976, vol. 8, 878-91; “A Resolution for the Creation of a Local Government Advisory Council of the Southern Growth Policies Board," May 31, 1978, folder Executive Committee, June 21, 1978, Atlanta, box 23, subseries 1.3, SGPBP; “A 'Hell of an Experiment' in
} 
efforts to link public to private capital for innovation and to drape those efforts in the legitimating garb of the Cold War or the New Deal.

Yet state and local leaders did not simply give up on traditional industrial sectors. In Massachusetts, where political pressure to support declining sectors remained strong, officials showered public subsidies on traditional industry. Governor Dukakis's Massachusetts Industrial Finance Agency, established in 1978, delivered an astounding number of subsidies for plant modernization and expansion through Industrial Development Bonds (IDBs), a federally tax-exempt bond instrument with deep roots in southern efforts to recruit northern industry. Between 1978 and 1985, the communities targeted with the greatest number of bonds (total in parentheses) suggests the degree to which officials focused on manufacturing communities like Boston (103), Worcester (61), New Bedford (49), Lowell (47), Fall River (32), and Lawrence (26). While the total number of IDBs floated during this period is remarkable-2,059-the amount directed to the state's older industries is especially striking: $\$ 3.7$ billion in sub-market rate financing, with two-thirds directed to firms established prior to 1920 or between 1920 and 1969. The results were discouraging. In 1978, the average bond produced 107 jobs; by 1985, the figure was just 21, and the cost of financing a single manufacturing job soared from $\$ 13,604$ to $\$ 96,182$. And yet, Massachusetts typified national efforts to use IDBs to resuscitate traditional industry. Prior to 1965, four southern states accounted for roughly 80 percent of the total IDB market, which as late as 1960 amounted to only $\$ 100$ million annually. By 1968, 40 states floated an estimated $\$ 1.8$ billion in IDBs. By 1984, every state deployed the stimulus and together issued at least $\$ 17.4$ billion in federally tax-exempt financing for traditional industries in a single year. Still, the nation hemorrhaged manufacturing jobs: in 1977, 13.7 million Americans worked in manufacturing; in 1986, the total was 11.8 million. $^{30}$

Politicians discovered that the problem of global competition for manufacturing would not easily be solved by subsidies for plant expansions or modernization. While some firms moved to the South or headed to Singapore, South Korea, or Brazil, the economist Barry Bluestone noted that the root cause of the crisis was more basic: "firms closed down." For those remaining, capital mobility afforded leverage to negotiate concessions from workers and government. IDBs proliferated thanks to these pressures. Bluestone argued that reindustrialization of "sunset" industries would be desirable, if possible. But a better reindustrialization policy would offset declining sectors with efforts to "reabsorb" workers "into equivalent jobs" in new sectors. "To rectify this problem," he concluded, "requires either a massive effort at improving absorptive capacity through retraining and migration, a slowing of dislocation through various sectoral and regional industrial policies, or both." Bluestone's analysis was paralleled by the findings of David Birch, who led MIT's Program on Neighborhood and Regional Change. His influential report, "The Job Generation Process," argued that imbalances in regional economic vitality had less to do with firm death rates (which, he argued, were fairly regular) and more to do with their replacement rate. Birch's analysis of over 6 million businesses between 1969 and 1976 found that the most successful regions had high rates of business innovation and failure. Of 20 million jobs created, Birch found that only 5 percent were in manufacturing, while 90 percent were in the "information," "knowledge," or "service" sectors. While

Resolving Economic Growth," National Journal, Jan. 21, 1978; "Regional Groups Talk About Cooperation, But They Continue to Feud," National Journal, May 27, 1978, https:/www.nationaljournal.com/s/362113/federalismregional-groups-talk-about-cooperation-they-continue-feud? [accessed May 21, 2019]; Michael Harrington and Frank Horton, "Rescuing the Region," NYT, July 1, 1977, 17.

${ }^{30}$ James C. Cobb, The Selling of the South: The Southern Crusade for Industrial Development, 1936-1990 (Urbana, IL, 1993), ch. 2; “The Massachusetts Industrial Finance Agency: A Performance Audit," A Report of the Senate Committee on Post Audit and Oversight (Boston, 1986), Dewey Library, Massachusetts Institute of Technology, Cambridge, MA; Eisinger, Entrepreneurial State, 157; Koistinen, Confronting Decline, 222. 
Birch's methods and findings have since come in for criticism, when first published his report made an immediate political impact. ${ }^{31}$

\section{New Democrats Discover Post-Industrial Policy}

Beyond the findings of economists like Birch and Bluestone, a range of other dynamics encouraged New Democrats to look to new sectors of the economy. In deindustrializing cities, the property tax burden fell most heavily on homeowners, many of whom gained a foothold in the middle class owing to family wages delivered by unionized, industrial employment. As those industries closed-and as their tax dollars shriveled-cities across the Northeast and Midwest stared down looming fiscal crises, and residents, squeezed by new economic pressures, rejected higher property tax rates. In 1977, the U.S. Advisory Council on Intergovernmental Relations released a report entitled "Measuring the Fiscal 'Blood Pressure' of the States, 1964-1975." Massachusetts and New York, among eleven other disproportionately northern states (along with California), faced "high and rising" fiscal blood pressure. Massachusetts's state legislators called for dramatic cuts to the budget, and, over the summer of 1978, some even urged that the ratified budget be recalled and slashed mid-session. As tax revolts exploded across the commonwealth, Governor Dukakis lost his Democratic primary to an insurgent who pledged to limit tax rates. Nationally, social spending also came under intense scrutiny-well before Reagan's revolution. Congress, dominated by Democrats, was particularly cool to new spending measures. According to Americans for Democratic Action, by 1979 no region in the country saw its Democratic representatives sour on social spending and increased budgets more than the North. Even New Deal Democrats feared being tarred as "budget buster[s]," said Senator Ed Muskie. "It's true," he said; it "muted" his calls for spending programs, too. ${ }^{32}$

Meanwhile, Republicans worked to tie the late 1970s tax revolts, which began as local revolts over property levies, to an electoral strategy centered on cutting federal income taxes. The Kemp-Roth Tax Cut proposals called for dramatic cuts across all income-tax brackets, and in his third attempt for a seat in the U.S. House, Newt Gingrich found that the plan was "working more effectively than any issue I have discussed in 5 years of campaigning." In a memo to Georgia's Republican Party chairman, Gingrich was dazzled by "ITS POTENTIAL TO CREATE A CONSERVATIVE MAJORITY IN THIS COUNTRY.” In the stagflationary 1970s, even states with low fiscal blood pressure saw voters lash back against attempts to extract resources from residents. In Arkansas, which had a "low and falling" blood pressure, Governor Bill Clinton went down in defeat in 1980 in large measure for hiking automobile registration fees to pay for infrastructure improvements. ${ }^{33}$ Throughout the country, fiscal pressures on state and local governments and inflationary pressures on voters forced officials to make

\footnotetext{
${ }^{31}$ Barry Bluestone, "Deindustrialization and Unemployment in America," in Paul D. Staudohar and Holly E. Brown, eds., Deindustrialization and Plant Closure (Lexington, MA, 1987), 3-15, here 6; Bluestone, "In Support of the Deindustrialization Thesis," 51-2; Rothenberg, The Neoliberals, 75-84; for one critical reassessment of Birch's findings, see Charles Brown, James Hamilton, and James Medoff, Employers Large and Small (Cambridge, MA, 1990).

${ }^{32}$ Advisory Council on Intergovernmental Relations, "Measuring the Fiscal 'Blood Pressure' of the States-19641975” (Washington, DC, Feb. 1977), iii; Michael Knight, “Tax Revolt Ripples Sway Massachusetts,” NYT, June 27, 1978, A10; Geismer, Don't Blame Us, 257-9. On social welfare spending in Massachusetts, see Jamie Peck, "Postwelfare Massachusetts," Economic Geography 74 (Mar. 1998), 62-82; on the fiscal crises of the 1970s and their impact on social policy, see Edward Berkowitz, "The 1970's as Policy Watershed," Social Welfare History Project, 2011, https://socialwelfare.library.vcu.edu/eras/the-1970s-as-policy-watershed/ [accessed Mar. 11, 2019]; Dennis Farney, “The Dwindling Band of Liberals," WSJ, Jan. 15, 1979, 20; “Congress and Carter: Who's in Charge?" NYT, Jan. 30, 1977, 11.

${ }^{33}$ Newt Gingrich to Mack Mattingly, Mar. 1978, folder March 1978 memo, box 37, Newt Gingrich Papers, West Georgia University, Carrolton, Georgia [hereafter NGP]; Kurt Andersen, "Fresh Faces in the Mansions," Time, Nov. 15, 1982, 30-2; David Lauter, “Clinton Arkansas Record: He Won a Few, Lost a Few," LAT, May 23, 1992 , A1.
} 
grim tax or budgetary decisions or risk Clinton's and Dukakis's fate. Constrained by state constitutional prohibitions against running deficits, state and local officials considered some combination of three options: raising taxes, cutting services, or embracing a politics of economic growth that might grow the tax base and, in the long run, transcend these sorts of zero-sum, distributional questions. For New Democrats, the choice was clear.

Though they hardly knew it, no intellectual or ideological commitment better linked them to the New Deal's supply side than did this emphasis on the economic basis of social progress. Randall Rothenberg, a journalist and champion of this rising cadre of liberals, sought to popularize these ideas and to unify Democrats around this political outlook. As he explained it, "if growth was necessary to liberal values" - that is, if progressive social programs required revenue- "then liberals must learn to esteem those who provide growth." New Jersey Democrat Bill Bradley was less cautious, arguing in 1980 that "social issues are secondary ... to the health of the economy." Colorado's Gary Hart worked to finesse this emphasis on economic initiatives over social policies: "What is changing are not principles, goals, aspirations, or ideals, but methods. Very important that the distinction be made." Rothenberg underscored the challenges the rising generation faced. The "new economic era ... was more complicated, harder to respond to. It required new ideas." Overlooking the history of liberalism's supply side, Rothenberg even criticized New Dealers for their "loss of faith in the private sector" and "centralization." In contrast, the "neoliberals," as he called them, would emphasize entrepreneurialism, microeconomic structural interventions, and restoring public wealth. ${ }^{34}$

If the tax revolts, ineffectiveness of reindustrialization efforts, and public sector fiscal crises pushed New Democrats to emphasize new economic sectors, cultural dynamics played an important role, too. New Democrats shared a broader generational skepticism of the dominant institutions of American life that encouraged the New Left and the New Right to reject bureaucracy and centralization (albeit for differing reasons). In his famous "Name the System" speech, for instance, activist Paul Potter condemned the warfare state, but he also targeted bureaucracies that stripped individuals of moral agency and creativity. This was a theme steeped in the New Left's founding document, Students for a Democratic Society's "Port Huron Statement." At the same time, "creativity" and "innovation" gained heightened salience as a sort of cultural and personal prophylaxis against independence crushing bureaucracies. In 1963, one commentator described creativity as "a word of dizzying popularity ... [as] part of a growing resistance to the tyranny of formula, a new respect for individuality." By the late 1970s, this ethos of creativity and the quest for personal authenticity drove the ascendant vogue for entrepreneurialism, which came to inform New Democrats' approach to governance and their eventual enthusiasm for post-industrial sectors. ${ }^{35}$

The Massachusetts Technology Development Corporation (MTDC) became an influential if esoteric expression of these broader political, economic, and cultural dynamics that situated economic innovation at the root end of a progressive vision of governance. Established in 1978 by Governor Dukakis just before his primary defeat, the MTDC delivered public investments to fill the "existing 'capital gap' for ... early-stage technology companies." Initially

\footnotetext{
${ }^{34}$ Rothenberg, The Neoliberals, 68, 17-20, 30-1.

${ }^{35}$ On Port Huron and SDS's critique of the Democratic Party and bureaucracy, see Sam Rosenfeld, The Polarizers: Postwar Architects of Our Partisan Era (Chicago, 2018), ch. 4. On this generational and cultural ethos more broadly, see Grace Elizabeth Hale, A Nation of Outsiders: How the White Middle Class Fell in Love with Rebellion in Postwar America (New York, 2011); and Fred Turner, From Counterculture to Cyberculture: Stewart Brand, the Whole Earth Network, and the Rise of Digital Utopianism (Chicago, 2006). Cowie, Stayin' Alive, Introduction and ch. 1; Jamie Cohen-Cole, The Open Mind: Cold War Politics and the Sciences of Human Nature (Chicago, 2014), 1; on the 1970s and the rise of cultures of entrepreneurialism across the ideological spectrum, see, Bethany Moreton, To Serve God and Wal-Mart: The Making of Christian Free Enterprise (Cambridge, MA, 2009); and Joshua Clark Davis, From Head Shops to Whole Foods: The Rise and Fall of Activist Entrepreneurs (New York, 2017).
} 
funded with a \$2 million federal Economic Development Administration grant and a smaller pool of state funds, the MTDC invested in "companies which have the capacity to generate significant employment growth, but which have been unable to secure from private sources sufficient capital." As the prime interest rate crept past 17 percent, this "capital gap" loomed widest for smaller, unproven startups seeking smaller investments at more frequent intervals. As larger-scale investors moved to higher-yield or safer investments, "patient" forms of capital for smaller, riskier ventures evaporated. By delivering public financing to close this gap, the state of Massachusetts took equity stakes in private start-ups. ${ }^{36}$

While some MTDC board members, businesspeople, and academics were skeptical they could identify promising startups, another member reminded them that "whether we experience more successes or more failure is not the criterion. What we are trying to do is to create jobs" and state tax revenue. That is "the proper criteria of success." Each year's annual report began by detailing the new jobs and tax revenues the MTDC's investments had stimulated, and those considerations remained paramount in each investment decision. A \$100,000 investment in photovoltaics cell manufacturer Solenergy Corporation, for instance, stressed the company's "reasonable potential to create a substantial amount of primary employment within the Commonwealth." A $\$ 250,000$ investment in cathode ray tube lens manufacturer Display Components, Inc. cited the company's plans to grow from 80 employees in 1979 to 280 by 1981, with most jobs "taken by unskilled and semiskilled persons." As the prime interest rate reached a record high of 21.5 percent in December 1980, private investment markets tightened further, and the MTDC began receiving even stronger proposals. "We aren't seeing 'sick animals,"' said one board member in 1980. One highly skeptical board member soon became "very high on the MTDC." By 1993, new employment estimates topped 5,000, which generated some $\$ 15$ million in state tax revenue and \$85 million in federal revenues: $\$ 100$ million in new public wealth. ${ }^{37}$

Dukakis's program had drawn water from a stone, and in ways that squared ostensibly progressive ends like job and tax generation with the market-oriented ethos of the 1980s; the MTDC was his "new liberal" creed come to life. The program also plausibly deemphasized the state's role, despite the plain fact that taking equity stakes in start-ups was far more interventionist and riskier than postwar liberalism's contracting, R\&D spending, or infrastructure investments had ever been. The key, officials discovered, was highlighting entrepreneurialism, a high-tech future, and officials' business-like, non-bureaucratic outlooks. One annual report described how "MTDC began and grew just like the start-up companies it backs. It was launched as a concept with a modest operating budget" and then took off. Reelected as governor in 1982, Dukakis argued the MTDC could even outdo the private sector. In his 1988 book Creating the Future, written with an eye on the White House, Dukakis described a private sector venture capitalist who slept through a pitch by the software startup Interleaf. Meanwhile,

\footnotetext{
${ }^{36}$ Daniel Bell, The Coming of Post-Industrial Society: A Venture in Social Forecasting (New York, 1973); Massachusetts Technology Development Corporation, undated report, 1, Dewey Library, Massachusetts Institute of Technology, Cambridge, MA; Minutes of the Mar. 4, 1980 Meeting of the Board of Directors of the MTDC, attached to Irving Sacks to MTDC Board of Directors, Mar. 26, 1980, folder MTDC FY80, box 6, Massachusetts Institute of Technology, Institute Archives and Special Collections, Cambridge, Massachusetts [hereafter MIT-IASC]; Minutes of the June 15, 1979 Meeting of the Board of Directors of the MTDC, folder MTDC Minutes, box 6, MIT-IASC.

${ }^{37}$ Minutes of the Jan. 24, 1979 Meeting of the Board of Directors of the MTDC, folder MTDC Minutes, box 6, MIT-IASC; MTDC Resolution Approving \$100,000 Loan to Solenergy Corporation, attached to Irving Sacks to MTDC Board of Directors, Nov. 30, 1979, folder MTDC Minutes, box 6, MIT-IASC; MTDC Resolution Approving \$250,000 Loan to Display Components, Inc. (Discom), attached to Irving Sacks to MTDC Board of Directors, Nov. 30, 1979, folder MTDC Minutes, box 6, MIT-IASC; Minutes of the Mar. 4, 1980 Meeting of the Board of Directors of the MTDC, attached to Irving Sacks to MTDC Board of Directors, Mar. 26, 1980, folder MTDC FY80, box 6, MIT-IASC; Joel Orlen to Jerome B. Wiesner, Jan. 16, 1980, Ibid.; MTDC Annual Report, 1993, 1-2, Dewey Library, MIT.
} 
"MTDC immediately grasped Interleafs market philosophy." With public venture capital, Interleaf took off. ${ }^{38}$

Other states took note. Economic Innovation International, a consulting firm to government and development associations, helped establish twenty-six state venture capital funds based on the MTDC model. The states, crowed one supporter, were becoming "fifty bubbling crucibles in an American national laboratory that is seeking a new formula for global economic success." In 1984, Arkansas Governor Bill Clinton hired a Massachusetts official to establish "the [state's] overall economic direction.” Like Dukakis, Clinton's reelection as governor in 1982 was based on his political reinvention as an entrepreneurial leader who would do more with less. Clinton soon established the Arkansas Science \& Technology Authority, the Arkansas Capital Corporation, and the Arkansas Development Finance Authority. ${ }^{39}$ Despite coming from very different political and economic contexts-one state seeking to transcend deindustrialization and the other hoping to overcome chronic underdevelopment-Clinton and Dukakis converged on shared economic strategy and political rationale: they would blaze a trail to a post-industrial future.

\section{Post-Industrial Policy in the 1980s}

State and local post-industrial policy exploded in the 1980s. Particularly influential in spreading the word was the Council of State Planning Agencies (CSPA), a policy development branch of the National Governors Association, which Bill Clinton chaired in 1986-1987. The CSPA also hired a Massachusetts planning official who worked with legislators and state officials to develop MTDC-style post-industrial policies. In the South, meanwhile, Democratic Governors Chuck Robb (Virginia), James Hunt (North Carolina), and Bob Graham (Florida) pushed the Southern Growth Policies Board to help establish public venture capital pools for "the jobs of tomorrow." They had the support of grassroots business-types, too: one Georgia chamber of commerce argued that government must "make sure that venture capital is available" since "small business and rural entrepreneurs often have trouble securing loans." 40

Faced not only with interregional but also with global competition, businesspeople and politicians of all stripes discovered the value of post-industrial policy. The potent specter of Japan's industrial policy, run through its Ministry of International Trade and Industry, led to jeremiads with titles such as In the Shadow of the Rising Sun. Even politicians who led comparatively rich states understood their prosperity in relative terms and in the context of accelerating global competition. California paced the world in microcomputing technology, but Governor Jerry Brown supported post-industrial policies to maintain and expand that edge. Brown, whose fiscal moderation (some charged penury) produced budget surpluses in the late 1970s, called to "reinvest" those resources in the private sector through grants and public venture capital funding; he also called for a $\$ 7.6$ million partnership between entrepreneurs, industry, and the

\footnotetext{
${ }^{38}$ MTDC Annual Report, 1998, 2-3, Dewey Library, MIT; David Warsh, "Unwanted Winner: Strange Case of Materials Science," Boston Globe, June 5, 1988, A1; "Interleaf Soars on Software Maker's New Product," Bloomberg, December 1, 1999.

${ }^{39}$ John F. Hodgman, The Massachusetts Technology Development Corporation: How the Massachusetts Venture Capital Firm Leveraged Private Investments to Create Jobs (Bloomington, IN, 2015), 40-3; Scott Fosler, The New Economic Role of American States: Strategies in a Competitive World Economy (New York, 1991), 3; David Maraniss, "How Clinton Moved to Handle State's Economy," WP, Oct. 18, 1992, A1.

${ }^{40}$ On public VC in the 1980s, see Peter S. Fisher, "State Venture Capital Funds as an Economic Development Strategy," Journal of the American Planning Association 54, no. 2 (Spring 1988), 166-77; Michael Barker, ed., Financing State and Local Economic Development (Durham, NC, 1983), 246; Rothenberg, The Neoliberals, 1513 and 157; Anniversary Conference Proceedings, "Cooperative Growth Strategies for the 80s," folder Annual Meeting, 6/3/82, RTD, box 24, subseries 1.3, SGPBP; Rome, Georgia Chamber of Commerce, Forum, Apr. 1983, Hargrett Special Collections Library, University of Georgia, Athens, GA.
} 
state's universities. By the early 1980s, Brown talked incessantly about "targeting" investments in "emerging industries" and "identifying growth sectors." For Brown, the risk was that "our economic growth is reaching a plateau" and, as The Christian Science Monitor summarized it, "government and business must counter the thrust from Japan and other countries such as West Germany." A self-described "new liberal," Brown also emphasized the progressive rationale for focusing on the supply side: "It is not enough to say let us help those who are less fortunate." "No society," he explained, "has operated on just that principle. We have to ... build the economic strength of the country and do so in a context of social equity."

As state-level industrial policies flourished, the nation waged its first significant national industrial policy debates since the 1930s and 1940s. Yet, despite the explosion of subnational programs, the debate revolved around the question of whether the United States should establish an industrial policy at all. As Larry Fox, vice president of the arch-conservative National Association of Manufacturers, put it, "Industrial policy is only a problem for the United States because only the United States doesn't have an industrial policy." Federalism, historical amnesia about local industrial policy following the New Deal, and a tendency to nationalize major political issues ensured that for much of the 1980s the industrial policy debate failed to account for the proliferation of state and local post-industrial policy. Massachusetts Senator Ted Kennedy's “American Reindustrialization Corporation," for example, was a key proposal in his 1980 presidential primary challenge to President Jimmy Carter. But the \$1 billion figure Kennedy proposed to fund his bank was a drop in the bucket compared to the explosion of IDBs at the state and local levels; Kennedy's home state alone issued nearly $\$ 4$ billion in reindustrialization bonds between 1978 and 1985, suggesting just how out of touch the national debate was from local realities. Even those who acknowledged state or local efforts tended to dismiss them as ad hoc precursors to more cohesive national initiatives. In 1982, Robert Reich and Ira Magaziner published Minding America's Business, which, in calling for national planning, dismissed state efforts as "industrial policy by default." In contrast to Reagan's supply-side tax cuts, Reich and Magaziner envisioned a "truly 'supply' side series of policies" based on national, centralized investments and planning. ${ }^{42}$ Though they noted that West Germany employed federalism to decentralize stimulus, they did not recognize in American federalism a similar opportunity.

Meanwhile, advocates of traditional industrial policy watched with growing concern as New Democrats emphasized new sectors and some spoke in increasingly flippant ways about wasting public resources on struggling industries while mobilizing supply-side discourse that seemed also to echo the Reagan administration. At one point, Reich even seemed to out-Reagan Reagan, suggesting that the president's bailout of Chrysler "might not have been worth its salt." Though Reich was in fact calling for a more comprehensive program, whatever nuance he felt his ideas had escaped his critics. One United Steel union official charged, "You cannot glibly write off whole segments of industries." A representative of the United Automobile Workers called Reich's rhetoric "incredible." Labor must have been especially suspicious about the range of corporate elites who gravitated toward New Democrats' emerging postindustrial vision. ${ }^{43}$ As New Democrats gained confidence and clout, liberals' intramural antagonism would only grow.

\footnotetext{
${ }^{41}$ William S. Dietrich, In the Shadow of the Rising Sun: The Political Roots of American Economic Decline (University Park, PA, 1991); George F. Will, “Jerry Brown: Ideas for a Party in Need," WP, Dec. 6, 1981, C7; Sara Terry, "How Jerry Brown Envisions 'Investing in the Future," Christian Science Monitor, Feb. 12, 1981.

${ }^{42}$ Ira C. Magaziner and Robert B. Reich, Minding America's Business: The Decline and Rise of the American Economy (New York, 1982), 330.

${ }^{43}$ Stein, Pivotal Decade, 245; Harry Bernstein, “U.S. Industrial Policy Debate Still Goes On,” LAT, June 12, 1985, C1; Rothenberg, The Neoliberals, 91; T. R. Reid, "Kennedy: 'Reindustrialize' the U.S.: Urges Government, Private Funding," WP, May 21, 1980, A4; Business Week devoted its entire June 20, 1980 issue to exploring industrial policy ideas; John Herbers, "Nationwide Renewal of Public Works Urged," NYT, Apr. 5, 1981, 26; Graham, Losing Time,
} 
If politicians rediscovered the market in the 1980s, many did so with the tools of public policy. Though the national industrial policy debate floundered during the supposedly "free market" renaissance of the 1980s, state and local government subsidized growth associations and institutions, university-based business incubators, research parks, venture capital pools, equity funds, and planning partnerships flourished. By 1983, 153 distinct state-supported programs pursued everything from conventional recruitment tactics like site improvements and "technical assistance" to new forms of high-tech $\mathrm{R} \& \mathrm{D}$ transfers and venture capital funds. Georgia created the Georgia Research Alliance, a \$30 million entrepreneur incubator and "public/private cooperative venture" at Georgia Tech designed "to build a high technology industrial base" and to open public-to-private technology transfer centers across the state. In 1988, a poll of businesspeople conducted by the Business Council of Georgia found overwhelming support for post-industrial policy: 96 percent "agree[d] that 'managing growth through coordinated planning at the local, regional, and state level is important to Georgia's future."” Eighty-six percent called for increased taxes to fund infrastructure and education tailored to new economic sectors. $^{44}$

Despite such ubiquity, advocates' market-oriented, entrepreneurial rhetoric and their decentralized nature made these interventions difficult to comprehend in their totality. Precisely because it shaded the government's role, the purportedly non-ideological discourse of entrepreneurialism also enabled pragmatically minded, state-level Republicans to pursue post-industrial policy at the moment when the national party lurched toward embracing "free markets." In Pennsylvania, Republican Governor Dick Thornburgh established the Ben Franklin Partnership with more than $\$ 100$ million in public and private contributions. As one state venture capital director put it, "The climate has been set for the entrepreneur." One Pennsylvanian praised the programs in similar terms. "I'm a free market man myself," he said, "but I see merit in setting in motion the natural evolutionary trends." The "natural" market trends simply needed a nudge. Across the border in Ohio, the $\$ 70$ million "Edison" program established six regionally tailored development programs-supporting biotech in Cleveland, for instance. The programs' director described the policies as "the same stuff" of the industrial policy debates: "we just didn't have a big debate about it.... If you stop 15 Fortune 500 types in Ohio and ask what's the best thing [Dem. Gov. Richard] Celeste has done, they'll say the Edison program." As Charles Peters, a journalist and champion of the New Democrats, explained it, "Our hero is the risk-taking entrepreneur who creates new jobs and better products." The director of Cleveland's initiative used similar terms: the program enabled the city to "make love to our entrepreneurs." 45

53-5; "U.S. Industry Seeking to Restore Competitive Vitality to Products," NYT, Aug. 18, 1980, A1; "Business Forum: Why the U.S. Needs a Development Bank, The Only Source of 'Patient Capital,"' NYT, Oct. 16, 1983, F3; and Stein, Pivotal Decade, 248-9.

${ }^{44}$ Robert C. McMath, Jr., et al, Engineering the New South: Georgia Tech, 1885-1985 (Athens, GA, 1985), 437-8; "Harris Announces \$30 Million Research Consortium," Press Release, May 27, 1983, GAA; and "Beginning Thoughts on Georgia's Economy and Capital Markets," June 14, 1989, 10, folder Growth Strategies Commission, Capital Markets-June, 1989, RCB-14937, GAA; By 2002, Tech ran 18 incubators and R\&D centers funded with \$276 million in state revenues. John Sibley to Joe Frank Harris, Dec. 2, 1988, folder Growth Strategies Commission: Correspondence-Dec., 1988, RCB-14935, GAA; Louis G. Tornatzky, Paul G. Waugaman, and Dennis O. Gray, "Innovation U: New University Roles in a Knowledge Economy," Southern Growth Policies Board (Southern Technology Council, 2002), 28-31.

${ }^{45}$ Charles Peters, “A Neo-Liberal's Manifesto," WP, Sept. 5, 1982, C1; "States Try New Routes to Reviving Industries," NYT, Nov. 30, 1985, 8; "New High-Tech Council President Is Named in Montgomery County," WP, Sept. 15, 1986, WB14; David M. Erdman, "Politicians Picture High Tech as Elixir for Economic Ills," Allentown Morning Call, Feb. 22, 1987, D8; Joel Kotkin and Greg Critser, "Capitol Ideas," Inc., Oct. 1, 1985; "You Want to Compete with Japan? Ask Ohio," WP, Dec. 21, 1986, D1; "Richard Shatten," Crain's Cleveland Business, May 24, 2010. 
For many, the intermediating institutions of chambers of commerce, subnational governments, or university expertise obscured the government's role in these processes. Expressions of support poured in for these initiatives, but the expressions themselves often revealed the degree to which public investments in private growth were being obscured by "free market" rhetoric, "entrepreneurialism," and mythologies of limited government. A small business owner in northwest Georgia described the help she received from the state: "The great American free enterprise system continues to tell us: ... 'only in America, and better still ... IN GEORGIA', are these ventures not only possible, but ultimately successful!" When asked if his state's efforts to establish a venture capital fund amounted to "industrial policy," Michigan's Democratic Governor James Blanchard described the more pragmatic nature of state and local governments: "We don't use the term," because it "polarizes politics on abstractions." His was a "policy of jobs and economic development." The financier Felix Rohatyn predicted state-level efforts would eventually shape federal policies, too. Would they be called industrial policy? Said Rohatyn, "Never heard of the words." Another supporter explained that these initiatives operated on "the quiet side of public spending." 46 Yet, while officials were pleased their programs were met with enthusiasm, this was a thin sort of political legitimacy, based upon mediating institutions, market outcomes, and a rhetorical veneration of entrepreneurialism rather than on a clear understanding of the foundational role public resources played in these processes.

Even as close a student of the political economy as Robert Reich struggled to see what was happening at the state and local levels. In 1986, however, he finally saw the light, declaring subnational post-industrial policies "the best-kept secret in America." By that point, at least 28 states sponsored hundreds of millions of dollars in public venture capital pools. And while social welfare spending increasingly faced the chopping block, by 1988, 45 states supported more than 250 entrepreneur-oriented technology development programs. By 1991, 116 new research parks had sprung up, most based on the Research Triangle model, with 85 percent receiving complete or partial public subsidization. ${ }^{47}$ As New Democrats sought both higher offices and greater influence within the party, the politics of growth and entrepreneurship would bind together young liberals from across the country. So, too, would the brash conviction that they had discovered the keys to transcending the zero-sum society.

\section{New Democrats Take Command}

Though Dukakis and other New Democrats liked to describe their politics as pragmatic or nonideological, theirs was rapidly becoming a profoundly ideological vision that would also come to shape their electoral strategies. Initially, emphasizing the economic basis of social progress had enabled New Democrats to frame their commitments to a broader social agenda in terms of "growing the pie" or ensuring a "rising tide." Though they understood their position to be pragmatic or non-ideological, invoking rising tides and bigger pies not only forestalled distributional questions, but it risked abandoning them altogether. As one of Dukakis's chief political strategists, John Sasso, put it in 1986, growth was becoming "an approach" to politics that "everybody can rally behind." Overlooking the fact that business constituencies were aggressively lobbying for this spending, Sasso claimed New Democrats' programs were "not driven by constituency politics." Yet he simultaneously laid bare New Democrats' emerging tilt toward a new cadre of voters. Post-industrial policy, he said, was winning support from "middle income people ... and the small business people, who [had] left the Democratic

\footnotetext{
${ }^{46}$ Julie V. Ouseley to Joe Frank Harris, Nov. 7, 1988, folder GA Tech Reg. Office, RCB-1506, GAA; "States Try New Routes to Reviving Industries," NYT, Nov. 30, 1985, 8; "You Want to Compete with Japan?, D1; David Broder, "New Deal-Making Politics," WP, Feb. 10, 1986, A1.

47"You Want to Compete with Japan?," D1; "Report Urges Federal Funds to Promote Technology Firms," WP, Oct. 1, 1992, D14; Luger, Technology in the Garden, 2.
} 
Party in droves" in the 1970s. While Paul Tsongas touted their "non-ideological" vision for its avoidance of "dogmatic blinders [and] ideological extremes," he also betrayed his own emerging biases, especially when it came to beneficiaries of particularly visible social welfare programs. "During the Sixties," he said, "there was this belief that poor people were somehow noble beings." In the 1980s, however, "Liberals have got to realize that some people just don't want to work." The economic pragmatism born in the 1970s fiscal crises was hardening into an ideology that would define New Democrats' suburban, white-collar, and post-industrial electoral strategies for decades to come. In the process, northerners like Tsongas were sounding a lot more like southern Democrats. ${ }^{48}$

In February 1985, a contingent of centrist, southern Democrats announced the formation of the DLC. Alvin From, aide to Louisiana Representative Gillis Long, was its first executive director, and other Sunbelt Democrats filled leadership positions: Georgia Senator Sam Nunn, Virginia Governor Chuck Robb, Florida Senator Lawton Chiles, Arizona Governor Bruce Babbitt, and Oklahoma Representative James Jones. As Nunn put it at their inaugural press conference, the goal was to "move the party-both in substance and perception-back into the mainstream of American political life." But what did this mean? DLC members were particularly suspicious of approaches to poverty and economic insecurity that foregrounded redistribution or entitlement programs. While progressive Democrats then, and many scholars since, have viewed this position as a rejection of New Deal commitments, this outlook had deep roots within the New Deal coalition, even if it had been marginalized within the national party, particularly its Congressional leadership, since the 1950s. Defined in large part by white, southern suspicion of central administration and regulatory authority, as well as support for elite, local prerogatives if not overt Jim Crow, many DLCers began their careers as critics of Great Society liberalism. In 1964, a young Georgia Democrat named Zell Miller campaigned for Congress by explicitly running against President Johnson's War on Poverty. Thanks to Lyndon Johnson, Miller charged, a majority of Americans' "individual freedoms are being sacrificed away bit by bit." Miller later chaired Georgia's DLC chapter. As Sam Nunn put it in his successful 1972 bid for U.S. Senate, "Cutting the budget and giving taxpayers a break will give the Washington bureaucrats something useful to do for a change." ${ }^{49}$ Southern New Democrats did not need a Reagan Revolution to define their positions on particular entitlement programs or bureaucracy.

Less a wholesale rejection of the New Deal, then, the DLC reflected the regional outlook and political instincts of its founders: southern, white, male Democrats. They hoped to extend those aspects of the New Deal that southern "centrists" had always embraced: a development agenda that emphasized business, entrepreneurship, and local control of federal resources. At their best, southern Democrats had always been ambivalent about the party's civil rights and labor agendas. The generation that came of age in the 1970s hoped those issues might recede in favor of "post-racial" and "post-industrial" growth policies; they founded organizations like the Southern Growth Policies Board to advance just such an agenda. In 1986, Governor Bill Clinton served an influential term as SGPB chairman during which he urged southern leaders to build "public-private partnerships which will increase the per capita income, reduce poverty, and reduce unemployment." But they had to spend their resources wisely. Because the South had "too much need and too little money," another SGPB report released under Clinton explained, officials "must spend local, state, and federal money where return will be

\footnotetext{
${ }^{48}$ Broder, "New Deal-Making Politics," A1; Rothenberg, “The Neoliberal Club," 40; on northern New Democrats' suburban strategy more broadly, see Geismer, Don't Blame Us.

${ }^{49}$ Jon F. Hale, "The Making of the New Democrats," Political Science Quarterly 110, no. 2 (Summer 1995): 207-32, here 215; "Landrum Linked to LBJ," People's Choice, News of the 9th District, Sept. 1966, folder 15, box 1, series II, Zell Miller Papers, Richard B. Russell Library, University of Georgia, Athens, GA; Tom Baxter, "Miller to Lead Ga. Democratic Council," Atlanta Constitution, Mar. 25, 1991; "Sam Nunn Campaigns on the Issues, Pledges to Get Tough in Washington," Nunn Campaign Materials, box 3, RCB-255, Legislature, Administrative Records, GAA.
} 
highest" - that is, where the "returns" were readily apparent. ${ }^{50}$ Social program expenditures might not yield immediate returns, and in any event, the 1970s had taught that redistribution in the context of austerity would accelerate social divisions. Economic growth was the key to prosperity and winning elections. That these preferences dovetailed with a growing segment of northern and western Democrats only accelerated southern Democrats' prominence within the national party.

For these men, no matter their region, setting aside questions of entitlements and distributional debates jived with their increasingly paternalistic sense of their sober, business-like decision making in an age of perceived limits. Dukakis described how his team "rolled up our sleeves and went to work" to save jobs and struggling communities. Given public sector scarcity, Rothenberg argued, these liberals saw that "you couldn't keep spitting on the people who created the wealth to pay for social programs." When it endorsed Dukakis for the presidency in 1988, the Philadelphia Inquirer ratified the self-image many New Democrats had cultivated: he "has never flinched at hard choices." A 1987 DLC forum featured a debate about social welfare programs in the context of the Reagan deficits, which many framed as an issue of growth rather than tax policy. Arizonan Bruce Babbitt excoriated liberals who failed to reject the "flim-flam" of new social spending programs without being "tough-minded" and demonstrating the "courage to stand up and say, here's what we're going to cut out of the budget, and here's" how "we're going to raise" revenues. A number of DLCers agreed with Richard Gephardt that the best assistance program "is a paycheck." No self-identifying "neoliberal" was clearer about the linkages between renewed growth, liberals' social agenda, and the importance of entrepreneurship than was Charles Peters. In a Washington Post article titled "A Neo-Liberal's Manifesto," he argued that "economic growth is most important now, because it is essential to almost everything else we want to achieve."

As the pillars of New Deal liberalism sustained withering defeats in the 1980s-labor, traditional industry, and the social safety net-New Democrats' narrow commitments to public "investments" that showed quick "returns" abetted these trends, relegating support for the poor or working class as expensive and ineffectual diversions from more fundamental economic concerns. For New Democrats like Gephardt, "the future of the American economy is in having the best thoughts, the best mental work, as opposed to having a workforce that is particularly adept at making things." Scott Fosler, a herald of the New Democrats, put a characteristically upbeat note on the relationship between austerity and innovation that reflected the emerging disregard for older sectors and displaced workers. "Sustained prosperity," he explained, "created dependencies and rigidities in habits and institutions that impeded the transition to new technologies and new industries. Decline," meanwhile, "tended eventually to loosen rigidities, curb costs, and compel experimentation with new approaches." Deindustrialization and fiscal crises, it turned out, had been like medicine, curing regions and leaders of old "dependencies" and inspiring new approaches to economic innovation. Collectivities like labor-a "workforce" or "human capital"-in the New Democrats' "classblind," supply-side synthesis, ultimately depended upon the success of innovative entrepreneurs. For New Democrats, governments' proper role was to support those entrepreneurs. ${ }^{52}$

By the second half of the 1980s, and as their influence within the party increased, New Democrats came under much more fire from critics for their increasingly blatant disregard for displaced workers, the poor, and the marginalized. Presidential candidate and Rainbow

\footnotetext{
${ }^{50}$ Doris Betts, "Halfway Home and a Long Way to Go," The Report of the 1986 Commission on the Future of the South, Southern Growth Policies Board, 1986, 4, 7.

${ }^{51}$ Thomas B. Edsall, "Engineering a Comeback: New Persona, Policies Buoy Second Term," WP, July 11, 1988, A1; Rothenberg, The Neoliberals, 71; “A Case for Dukakis," Philadelphia Inquirer, Oct. 30, 1988, C6; Robin Toner, "Economy Frames Democrats' Forum,” NYT, Nov. 3, 1987, D31; Peters, “A Neo-Liberal's Manifesto.”

${ }^{52}$ Peters, "A Neo-Liberal's Manifesto"; Rothenberg, The Neoliberals, 85; Fosler, The New Economic Role of the States, 3, 10. On New Democrats and "class blindness," see Geismer, Don't Blame Us, Introduction, 274-6.
} 
Coalition leader Jesse Jackson delivered particularly sharp critiques, charging that most New Democrats were little better than warmed-over Dixiecrats. The DLC, Jackson said, stood for "Democrats for the Leisure Class." Faced with growing criticism of their disregard for African American advancement in particular, most New Democrats retreated to ever-more-abstract talk about expanding "opportunity." At least one New Democrat, however, publicly rejected such abstract niceties. In 1986, Chuck Robb challenged his fellow DLC members to end their "conspiracy of silence and start a frank discussion about the obstacles to black progress." The time had come "to shift the primary focus from racism, the traditional enemy from without, to self-defeating patterns of behavior, the new enemy within." Robb effectively lent credence to Jackson's charge that the DLC was producing "schizophrenic leaders who want to look like John Kennedy with hair flowing to the left and act like Ronald Reagan with behavior flowing to the right." For his part, Al From sniped back at Jackson: his advocacy of the urban poor, struggling farmers, and displaced workers was "representative of old-style politics." One representative of that old-style Democratic party politics, Howard Metzenbaum, Ohio's veteran senator and longtime champion of organized labor, shot back: From "doesn't know shit from Shinola."53

If New Democrats failed to understand why so many traditional Democrats harbored skepticism for their economic policies, they also had a tenuous understanding of why their postindustrial policies thrived in an era of "free market" rhetoric and skepticism for government. In terms of political legitimacy, they overlooked the importance of the levels of government administering post-industrial policy. And, if they hoped to nationalize the programs, they also underestimated the necessity of forging a consensus around an urgent national cause to justify new federal subsidies. Without mastering the politics of federalism and scale, without declaring a new national priority or speaking clearly about government's critical role, and without offering a vision that meaningfully included the poor, the out of work, and the underemployed that might rouse an electoral mandate, establishing national post-industrial policies would be a singular challenge for President Bill Clinton.

\section{New Democrats, Newt's Right}

By 1991, Clinton had climbed the ranks of the DLC, and, as he began his presidential campaign, the economy sank into recession. An internal campaign mantra- "It's the economy, stupid"-quickly came to define his challenge to President George H. W. Bush. The phrase was simple; Clinton's plans for implementation were not. He had served an influential term as president of the SGPB, and, as Arkansas governor, Clinton built a system of high-tech venture capital pools. As president, Clinton planned to use national funds to subsidize, scale up, and coordinate state- and region-based post-industrial policies. His advisors solidified their plans during the summer of 1992, and Clinton soon pledged to devote $\$ 7$ billion of the post-Cold War "peace dividend" on civilian R\&D, doubling the budget of the National Institute of Standards and Technology (NIST) and establishing an agency to stimulate "high-risk, highpayoff technologies in the private sector." He would boost infrastructure investments and increase the $\$ 76$ billion in annual spending on basic industrial technologies. "This is a watershed," said Kent Hughes of the Council on Economic Competitiveness; "We're now going to develop an economic strategy much in the way that we developed a national strategy to fight the Cold War." Clinton announced plans to spend the same amount of money on economic competitiveness that Reagan had on Star Wars- $\$ 30$ billion-but in half the time. ${ }^{54}$

\footnotetext{
${ }^{53}$ Baer, Reinventing Democrats, 185; Phil Gailey, "From Biden to Babbit to Nunn," NYT, May 18, 1986, SM70; Robert A. Jordan, “DLC Gets Jesse Jackson's Dander Up,” Boston Globe, May 5, 1991, 87; Lloyd Grove, “Al From, the Life of the Party," WP, July 24, 1992, D1.

${ }^{54}$ Osborne, Laboratories of Democracy, 104-9; Gary H. Anthes, "High Tech, Clinton-Style," Computerworld, Oct. 26, 1992; "Clinton at Work on Economy," St. Petersburg Times, Nov. 10, 1992, 1 A.
} 
Despite the staggering scale of these proposed policies, the 1992 party platform also demonstrated New Democrats' emphasis on limited government. Put another way, their pursuit of growth would form the basis of their approach across practically all policy domains. "We reject both the do-nothing government of the last 12 years," the platform announced, "as well as the big government theory that says we can hamstring business and tax and spend our way to prosperity." Their "third way" would "honor business as a noble endeavor." They framed their "entrepreneurial economy of high-skill, high-wage jobs" as the "most important" approach to "family policy, urban policy, labor policy, minority policy, and foreign policy." 55 Liberalism's supply side was thriving.

Once in office, Clinton moved to harness and subsidize state-level post-industrial policies. Led by Vice President Al Gore and Robert Reich, the administration envisioned 170 locally run, federally funded technology and manufacturing "extension centers." Grasping for legitimizing precedents, Clinton said they might do for the economy "what the interstate highway of the 1950s did for the productivity of the nation's travel and distribution system." In his first inaugural address on January 20, 1993, Clinton echoed Franklin Roosevelt, calling for "bold, persistent, experimentation" to "create millions of long-term, good-paying jobs" through "a program to jumpstart our economy." The next month, Clinton unveiled his economic plan in a prime time address. In the plan, titled "Technology for America's Economic Growth: A New Direction to Build Economic Strength," the administration argued for public "investments where they'll do the most good: incentives to business to create new jobs; investments in education and training," and, as the Cold War ended, "special efforts for displaced defense workers." Faced with mounting global competition, the seemingly ad-hoc military Keynesianism of the Cold War would not do: the nation could no longer "rely on the serendipitous application of defense technology to the private sector." G. Kirk Raab, CEO of Genentech, a biotech company, was thrilled. "Fundamentally, it's the beginning of an industrial policy," he said, and "we need an industrial policy in the U.S." MIT economist Paul Krugman exceeded Raab's enthusiasm: "we have been crossing an intellectual watershed in economic policy, away from a belief in the magic of the marketplace toward a belief that markets are very good but not perfect things and they sometimes need a little help from Government." The administration resisted calling its initiative "industrial policy," but Clinton would not have quibbled. ${ }^{56}$

Almost immediately, however, Clinton faced significant challenges. Unexpected fiscal constraints came first. Al From, Clinton's domestic policy advisor, recalled that the campaign's projections of the federal deficit "just couldn't have been farther off." Reagan's tax cuts and defense spending had created a fiscal straightjacket, and key Clinton advisors, perhaps reminding the president of the state and local lessons of the 1970s, argued for addressing the deficit, lest bond markets react unfavorably. The second hurdle came in the early spring of 1993, when Republicans, led by Senator Bob Dole, filibustered Clinton's $\$ 16.3$ billion stimulus package, which included initial funding for his post-industrial policy within a larger jobs initiative.

\footnotetext{
55“1992 Democratic Party Platform," July 13, 1992. Online by Gerhard Peters and John T. Woolley, The American Presidency Project, https://www.presidency.ucsb.edu/documents/1992-democratic-party-platform [accessed Apr. 29, 2019].

56“Clinton to Promote High Technology with Gore in Charge," NYT, Nov. 10, 1992, C1. On Reich's role in the administration, see, "Clinton's Point Man on Economics," NYT, Nov. 21, 1992, 33. See also, Robert B. Reich, The Work of Nations: Preparing Ourselves for 21st-Century Capitalism (New York, 1991). William J. Clinton, Inaugural Address, Jan. 20, 1993, Online by Gerhard Peters and John T. Woolley, The American Presidency Project, https:// www.presidency.ucsb.edu/node/219347 [accessed Apr. 29, 2019]; William J. Clinton, Address to the Nation on the Economic Program, February 15, 1993, Online by Gerhard Peters and John T. Woolley, The American Presidency Project, https://www.presidency.ucsb.edu/node/218163 [accessed Apr. 29, 2019]; William J. Clinton and Albert Gore, Jr., "Technology for America's Economic Growth: A New Direction to Build Economic Strength," Feb. 22, 1993, available online, https://files.eric.ed.gov/fulltext/ED355929.pdf [accessed Apr. 29, 2019]; "Clinton Proposes Changes in Policy to Aid Technology," NYT, Feb. 23, 1993, A1; "Clinton's Point Man on Economics," 33; "Clinton Proposes Changes," A1.
} 
Attempting to overcome Republican opposition, in April, Clinton appeared at the first of five White House briefings on his "Technology Reinvestment Project," and promised something for every region of the country. Speaking in his clearest terms yet about the policies, Clinton explained that the "Federal Government will directly support commercial technology through industry consortia [and] regional technology alliances." While he tried to leaven his words with the language of partnerships and federalism, Clinton nevertheless invoked the fully state-sponsored character of industrial policy. ${ }^{57}$

Clinton's clarity challenged more than Republican opposition: he took on powerful national mythologies about purportedly limited U.S. government, preferences for free markets, and localism - mythologies through which liberalism's supply side had always operated and thus tacitly abetted. His transparency surprised many. The editors of The Economist, close if conservative spectators of political economy, recounted historical fictions about the United States's supposed lack of structural economic policies: "Ironically Mr. Clinton is embarking on an overt industrial policy just as America looks poised to win a great technology race precisely because it eschewed such direct government meddling." 58

The filibuster and the burdens of a misremembered past stacked the deck against Clinton as he faced his most potent challengers: a rising generation of Congressional conservative ideologues led by Georgia Representative Newt Gingrich. While state and local Republicans pragmatically avoided the term "industrial policy" because it "polarizes politics on abstractions," polarizing politics on abstractions practically defined Gingrich's approach to national politics. Gingrich's characterization of liberals' historical statism-an impression that some New Democrats helped popularize-inflated the distorted reading of liberalism that conservatives since the New Deal had equated with creeping socialism. It was Republicans, Gingrich claimed, who were the party of partnerships with "professional associations, private industry, neighborhood associations, and local governments." Gingrich's claims reflected a broader political common sense. When Clinton, for instance, adopted aspects of George H. W. Bush's "thousand points of light" campaign (a social vision of public-private partnerships and voluntarism), critics on the left charged Clinton with tacking to the right. ${ }^{59}$ Thanks to the long history of liberals who failed to establish a robust defense of their role in structuring these sorts of policies and partnerships, New Democrats' post-industrial plans lacked a set of legitimating concepts or rhetoric. By the 1990s, partisan debate had essentially narrowed to contests over which party offered the best partners for the private sector.

\footnotetext{
${ }^{57}$ Al From Interview, Apr. 27, 2006, William J. Clinton Presidential History Project, Miller Center, University of Virginia, available online, https://millercenter.org/the-presidency/presidential-oral-histories/al-oral-history2006domestic-policy-advisor-clinton [accessed Apr. 29, 2019]. Arguing for the importance of assuaging bond markets reflected views on public finance that were deeply ingrained at the state and local levels in the 1970s, where governments were often constitutionally forbidden from running long-term deficits. The subnational fiscal crises of the 1970s, then, may have taught lessons about credit ratings and public debt that did not necessarily apply to the federal government. On these debates within the administration, see Nelson Lichtenstein, "A Fabulous Failure: Clinton's 1990s and the Origins of Our Times," The American Prospect, Jan. 29, 2018, https://prospect.org/article/fabulous-failure-clinton\%E2\%80\%99s-1990s-and-origins-our-times; Jeffrey H. Birnbaum and David Rodgers, "GOP Filibuster Defeats Clinton on Stimulus Bill," WSJ, Apr. 22, 1993, A2; Helen Dewar, "Senate Action on Stimulus Bill is Put Off Until After Recess," WP, Apr. 6, 1993, A6; and "President Unapologetic on Jobs Bill that Dole, GOP Killed," WP, Apr. 26, 1993, A1; Paul Teske and Renee Johnson, "Moving towards an American Industrial Technology Policy," Policy Studies Journal 22, no. 2, (Summer 1994): 296-312; William J. Clinton, Remarks at the Technology Reinvestment Project Conference, Apr. 12, 1993, Online by Gerhard Peters and John T. Woolley, The American Presidency Project, https://www.presidency.ucsb.edu/node/219663 [accessed Apr. 29, 2019].

58“Do Not Adjust Your Set," The Economist, Feb. 27, 1993.

59"Speech to Republican Candidates \& Workers," Apr. 18, 1982, folder Speeches, box 32, NGP; "Bush's 'Points of Light' Volunteerism Burns On, With Clinton's Aid," NYT, Apr. 23, 1993, A22.
} 
And so, Clinton retreated to more tried, true, and submerged methods, using executive branch authority to expand existing technology development programs. In 1988, South Carolina Senator Fritz Hollings had inserted the Technology Competitiveness Act into the innocuously titled Omnibus Foreign Trade and Competitiveness Act. Hollings's title authorized federal subsidization of "dual use" technologies-military R\&D that could be transferred to civilian businesses. Three initial Manufacturing Technology Centers (MTC) were established in January 1989 in Albany, New York; Columbia, South Carolina; and Cleveland, Ohio. By 1993, NIST had opened four more centers in Michigan, Kansas, California, and Minnesota. In 1994, Clinton quietly planned to expand the program from seven to 100 centers, raised the funding for the MTC's parent agency from $\$ 68$ to $\$ 441$ million, and recruited a Defense Advanced Research Projects Agency (DARPA) administrator to oversee the expansion. ${ }^{60}$

But 1994 was also the year Newt Gingrich debuted his "Contract with America," his strategy to "nationalize ... congressional campaigns," as a Michigan ally explained. At Gingrich's urging, Republican candidates called for killing the Department of Commerce, which funded the MTCs. The programs, Gingrich charged, threatened the spirit of American free enterprise. As the Washington Post reported, Gingrich believed Commerce was "particularly worthy of extinction" since his generation of conservatives "reserve a special circle in their political hell for anything that remotely smacks of 'industrial policy."' As an ally explained, "We're trying to promote technological freedom and opportunity, as opposed to a Federal command-andcontrol system." To some, simply cutting federal programs for cutting's sake was justification enough. Department of Commerce Secretary Ron Brown considered it "absolutely ludicrous" that the United States would be "the only country in the world where the private sector has no seat at the Cabinet table." The Wall Street Journal, however, posited that Gingrich sought to kill Commerce for just that reason: to prevent "Mr. Clinton [from] build[ing] a bridge to business." 61

Gingrich failed to slay the Department of Commerce, but he succeeded in preventing Clinton from fulfilling his post-industrial policy and also blocked Clinton's plans for worker retraining. Gingrich had begun to decouple the subtle but thick relationship between national subsidies and the local private sector that had persisted throughout decades of Democratic leadership in Congress and the White House, and which had been essential to subsidizing liberalism's supply side. That this relationship had for so long traveled on "the quiet side of public spending" contributed to its durability. In Clinton's efforts to direct highly visible national funds toward resuscitating, formalizing, and nationalizing that system, this historical opacity proved a fatal flaw.

Despite New Democrats' enthusiasm for post-industrial policies and their proliferation in the 1980s and 1990s, they joined their New Deal forebears in obscuring liberalism's supply side in rhetoric favoring localism, free markets, and private sector partners. But New Dealers and New Democrats diverged in other, more critical ways. New Dealers worked to use redistributive programs and regulatory powers to ensure that an unprecedented number of Americans might enjoy new forms of economic security and opportunity—by supporting labor's right to bargain

\footnotetext{
${ }^{60}$ Shelley L. Hurt, "The Military's Hidden Hand: Examining the Dual-Use Origins of Biotechnology in the American Context, 1969-1972," in Fred Block and Matthew Keller, eds., State of Innovation, (Boulder, CO, 2011), 31-56; and C. T. Leonides, ed., "Manufacturing and Automation Systems: Techniques and Technologies," part 1 of 5 (San Diego, CA, 1992), 310-5; Block, "Swimming Against the Current,” 185.

${ }^{61}$ Kenneth J. Cooper, "GOP Offers a 'Contract' to Revive Reagan Years," WP, Sept. 28, 1994, A1; "Look for the New Makeup in Congress to Shake Up High-Tech Partnerships," WP, Nov. 11, 1994, C3; Edmund L. Andrews, "Outlook 1995: Technology and Media: Congress and White House Split on High Tech," NYT, Jan. 3, 1995, C19; "High-Tech Programs in Lawmakers' Sights," San Jose Mercury News, Sept. 24, 1995, 1D; David Rogers, “General Newt: GOP’s Rare Year Owes Much to How Gingrich Disciplined the House,” WSJ, Dec. 18, 1995, A1.
} 
collectively, for instance, or by insuring savings accounts or mortgages. In that sense, the New Deal's supply side was embedded within a broader set of positive social and economic programs designed to expand a majority of Americans' opportunity and security within the market system.

In contrast, when its aspirations to fund post-industrial policy were denied, the Clinton administration's political imagination contained little more than reverence for entrepreneurs, high-tech sectors, and a reflexive veneration of the market as the essential underwriter of social progress. As they sought alternative ways to get capital moving, and as interest rates ticked a bit higher in the mid-1990s, they reined in the deficit in hopes of reducing interest rates and reviving bond markets. But they also deregulated the financial sector with an eye toward unleashing private capital investments in new sectors and overcoming persistent barriers to home ownership, particularly for people of color. As Wall Street's technology bubble inflated the overall economy, and as a new bubble grew through predatory lending that "democratized" a deregulated mortgage market, Clinton and the New Democrats felt vindicated even in the absence of their post-industrial policy. Soon, Clinton's market-based poverty policy conceptualized the poor as unrealized entrepreneurs and impoverished communities as untapped "new markets."62

In the process, however, they gave up far more than they realized. Though New Democrats had not primarily generated their political and policy commitments in reaction to the New Right, their supposedly non-ideological politics of growth and entrepreneurship yielded a vanishingly limited historical, rhetorical, or political arsenal for authorizing or defending the state's role in the economy-let alone on behalf of other, more progressive social commitments. As conservatives chipped away at the social safety net and continued to slash tax rates, New Democrats' preoccupation with fiscal solvency and economic growth left them in a perennial game of partisan catch-up. As inequality exploded in the new millennium, it became clear that New Democrats had lost sight of more than just the places and people the new economy had left behind. In imagining that economic growth was sufficient for the task of redressing inequality and ensuring opportunity, New Democrats had cast aside New Dealers' other, more progressive rationale for emphasizing the supply side-generating the "public wealth" that might support new and expansive forms of collective economic security and social opportunity.

Brent Cebul is assistant professor of history at the University of Pennsylvania. His book project, Illusions of Progress: Business, Poverty, and Development in the American Century, is under contract with the University of Pennsylvania Press. With Lily Geismer and Mason B. Williams, he co-edited Shaped by the State: Toward a New Political History of the Twentieth Century (Chicago, 2019).

${ }^{62}$ Geismer, “Agents of Change." 